for conservation globally

Threatened

通
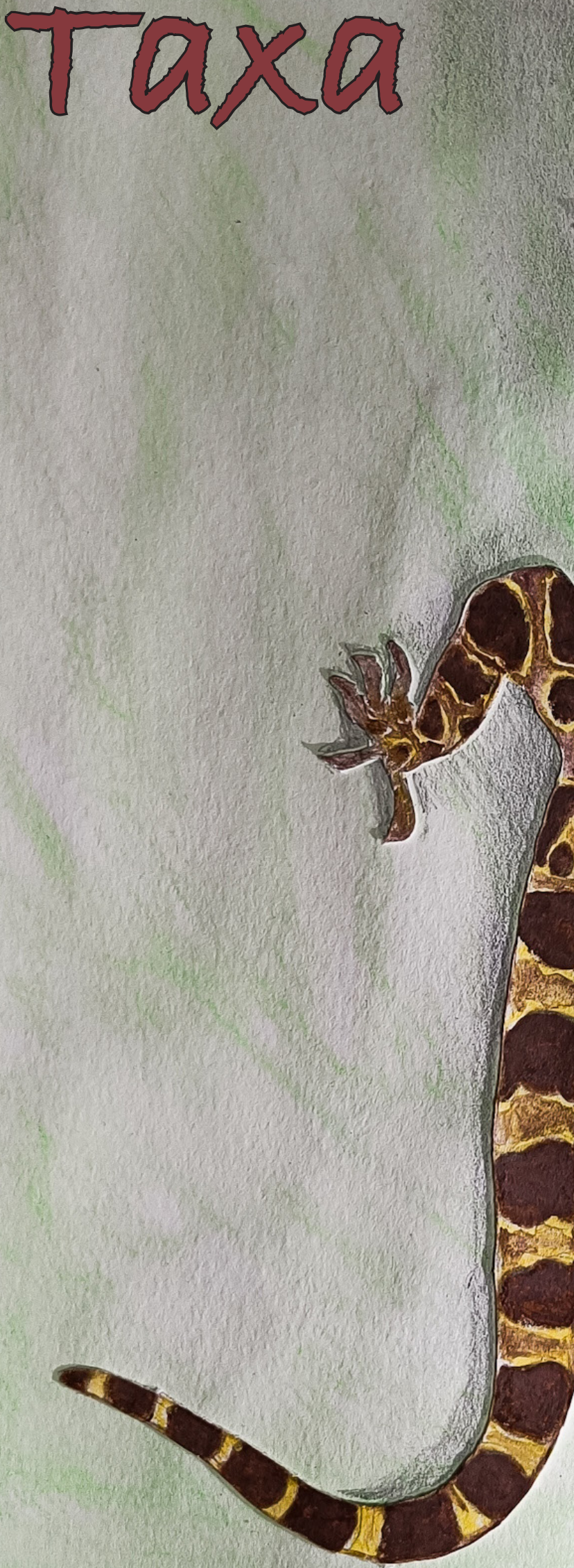

Open Access

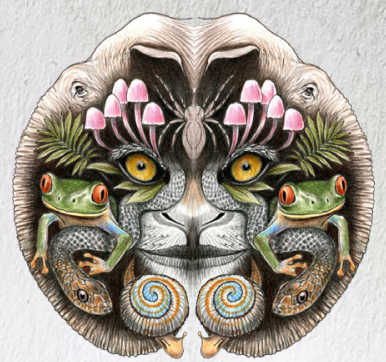

$10.1160 \mathrm{~g} / \mathrm{j}$ ott.2022.14.1.20311-20538 wWw.threatenedtaxa.org

26 January 2022 (Online \& Print) 14(1): 20311-20538 ISSN0974-7907 (Online) ISSN 0974-7893 (Print) 


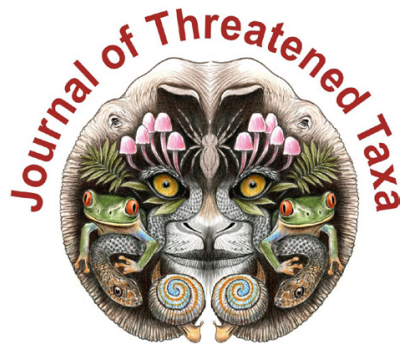

ISSN 0974-7907 (Online); ISSN $0974-7893$ (Print)

Publisher

Host

Wildlife Information Liaison Development Society

www.wild.zooreach.org

Zoo Outreach Organization www.zooreach.org

No. 12, Thiruvannamalai Nagar, Saravanampatti - Kalapatti Road, Saravanampatti, Coimbatore, Tamil Nadu 641035, India

Ph: +91 9385339863 | www.threatenedtaxa.org

Email: sanjay@threatenedtaxa.org

EDITORS

\section{Founder \& Chief Editor}

Dr. Sanjay Molur

Wildlife Information Liaison Development (WILD) Society \& Zoo Outreach Organization (ZOO),

12 Thiruvannamalai Nagar, Saravanampatti, Coimbatore, Tamil Nadu 641035, India

\section{Deputy Chief Editor}

Dr. Neelesh Dahanukar

Noida, Uttar Pradesh, India

\section{Managing Editor}

Mr. B. Ravichandran, WILD/ZOO, Coimbatore, India

\section{Associate Editors}

Dr. Mandar Paingankar, Government Science College Gadchiroli, Maharashtra 442605, India

Dr. Ulrike Streicher, Wildlife Veterinarian, Eugene, Oregon, USA

Ms. Priyanka Iyer, ZOO/WILD, Coimbatore, Tamil Nadu 641035, India

Dr. B.A. Daniel, ZOO/WILD, Coimbatore, Tamil Nadu 641035, India

\section{Editorial Board}

Dr. Russel Mittermeier

Executive Vice Chair, Conservation International, Arlington, Virginia 22202, USA

\section{Prof. Mewa Singh Ph.D., FASc, FNA, FNASc, FNAPsy}

Ramanna Fellow and Life-Long Distinguished Professor, Biopsychology Laboratory, and Institute of Excellence, University of Mysore, Mysuru, Karnataka 570006, India; Honorary Professor, Jawaharlal Nehru Centre for Advanced Scientific Research, Bangalore; and Adjunct Professor, National Institute of Advanced Studies, Bangalore

\section{Stephen D. Nash}

Scientific Illustrator, Conservation International, Dept. of Anatomical Sciences, Health Sciences Center, T-8, Room 045, Stony Brook University, Stony Brook, NY 11794-8081, USA

\section{Dr. Fred Pluthero}

Toronto, Canada

\section{Dr. Priya Davidar}

Sigur Nature Trust, Chadapatti, Mavinhalla PO, Nilgiris, Tamil Nadu 643223, India

\section{Dr. Martin Fisher}

Senior Associate Professor, Battcock Centre for Experimental Astrophysics, Cavendish

Laboratory, JJ Thomson Avenue, Cambridge CB3 OHE, UK

\section{Dr. John Fellowes}

Honorary Assistant Professor, The Kadoorie Institute, 8/F, T.T. Tsui Building, The University of Hong Kong, Pokfulam Road, Hong Kong

\section{Prof. Dr. Mirco Solé}

Universidade Estadual de Santa Cruz, Departamento de Ciências Biológicas, Vice-coordenado do Programa de Pós-Graduação em Zoologia, Rodovia Ilhéus/Itabuna, Km 16 (45662-000)

Salobrinho, Ilhéus - Bahia - Brasil

\section{Dr. Rajeev Raghavan}

Professor of Taxonomy, Kerala University of Fisheries \& Ocean Studies, Kochi, Kerala, India

\section{English Editors}

Mrs. Mira Bhojwani, Pune, India

Dr. Fred Pluthero, Toronto, Canad

Mr. P. Ilangovan, Chennai, India

Web Development

Mrs. Latha G. Ravikumar, ZOO/WILD, Coimbatore, India

\section{Typesetting}

Mr. Arul Jagadish, ZOO, Coimbatore, India

Mrs. Radhika, ZOO, Coimbatore, India

Mrs. Geetha, ZOO, Coimbatore India
Fundraising/Communications

Mrs. Payal B. Molur, Coimbatore, India

Subject Editors 2018-2020

Fungi

Dr. B. Shivaraju, Bengaluru, Karnataka, India

Dr. R.K. Verma, Tropical Forest Research Institute, Jabalpur, India

Dr. Vatsavaya S. Raju, Kakatiay University, Warangal, Andhra Pradesh, India

Dr. M. Krishnappa, Jnana Sahyadri, Kuvempu University, Shimoga, Karnataka, India

Dr. K.R. Sridhar, Mangalore University, Mangalagangotri, Mangalore, Karnataka, India

Dr. Gunjan Biswas, Vidyasagar University, Midnapore, West Bengal, India

\section{Plants}

Dr. G.P. Sinha, Botanical Survey of India, Allahabad, India

Dr. N.P. Balakrishnan, Ret. Joint Director, BSI, Coimbatore, India

Dr. Shonil Bhagwat, Open University and University of Oxford, UK

Prof. D.J. Bhat, Retd. Professor, Goa University, Goa, India

Dr. Ferdinando Boero, Università del Salento, Lecce, Italy

Dr. Dale R. Calder, Royal Ontaro Museum, Toronto, Ontario, Canada

Dr. Cleofas Cervancia, Univ. of Philippines Los Baños College Laguna, Philippines

Dr. F.B. Vincent Florens, University of Mauritius, Mauritius

Dr. Merlin Franco, Curtin University, Malaysia

Dr. V. Irudayaraj, St. Xavier's College, Palayamkottai, Tamil Nadu, India

Dr. B.S. Kholia, Botanical Survey of India, Gangtok, Sikkim, India

Dr. Pankaj Kumar, Kadoorie Farm and Botanic Garden Corporation, Hong Kong S.A.R., China

Dr. V. Sampath Kumar, Botanical Survey of India, Howrah, West Bengal, India

Dr. A.J. Solomon Raju, Andhra University, Visakhapatnam, India

Dr. Vijayasankar Raman, University of Mississippi, USA

Dr. B. Ravi Prasad Rao, Sri Krishnadevaraya University, Anantpur, India

Dr. K. Ravikumar, FRLHT, Bengaluru, Karnataka, India

Dr. Aparna Watve, Pune, Maharashtra, India

Dr. Qiang Liu, Xishuangbanna Tropical Botanical Garden, Yunnan, China

Dr. Noor Azhar Mohamed Shazili, Universiti Malaysia Terengganu, Kuala Terengganu, Malaysia

Dr. M.K. Vasudeva Rao, Shiv Ranjani Housing Society, Pune, Maharashtra, India

Prof. A.J. Solomon Raju, Andhra University, Visakhapatnam, India

Dr. Mandar Datar, Agharkar Research Institute, Pune, Maharashtra, India

Dr. M.K. Janarthanam, Goa University, Goa, India

Dr. K. Karthigeyan, Botanical Survey of India, India

Dr. Errol Vela, University of Montpellier, Montpellier, France

Dr. P. Lakshminarasimhan, Botanical Survey of India, Howrah, India

Dr. Larry R. Noblick, Montgomery Botanical Center, Miami, USA

Dr. K. Haridasan, Pallavur, Palakkad District, Kerala, India

Dr. Analinda Manila-Fajard, University of the Philippines Los Banos, Laguna, Philippines

Dr. P.A. Sinu, Central University of Kerala, Kasaragod, Kerala, India

Dr. Afroz Alam, Banasthali Vidyapith (accredited A grade by NAAC), Rajasthan, India

Dr. K.P. Rajesh, Zamorin's Guruvayurappan College, GA College PO, Kozhikode, Kerala, India

Dr. David E. Boufford, Harvard University Herbaria, Cambridge, MA 02138-2020, USA

Dr. Ritesh Kumar Choudhary, Agharkar Research Institute, Pune, Maharashtra, India

Dr. Navendu Page, Wildlife Institute of India, Chandrabani, Dehradun, Uttarakhand, India

\section{Invertebrates}

Dr. R.K. Avasthi, Rohtak University, Haryana, India

Dr. D.B. Bastawade, Maharashtra, India

Dr. Partha Pratim Bhattacharjee, Tripura University, Suryamaninagar, India

Dr. Kailash Chandra, Zoological Survey of India, Jabalpur, Madhya Pradesh, India

Dr. Ansie Dippenaar-Schoeman, University of Pretoria, Queenswood, South Africa

Dr. Rory Dow, National Museum of natural History Naturalis, The Netherlands

Dr. Brian Fisher, California Academy of Sciences, USA

Dr. Richard Gallon, llandudno, North Wales, LL30 1UP

Dr. Hemant V. Ghate, Modern College, Pune, India

Dr. M. Monwar Hossain, Jahangirnagar University, Dhaka, Bangladesh

Mr. Jatishwor Singh Irungbam, Biology Centre CAS, Branišovská, Czech Republic.

Dr. Ian J. Kitching, Natural History Museum, Cromwell Road, UK

Dr. George Mathew, Kerala Forest Research Institute, Peechi, India

For Focus, Scope, Aims, and Policies, visit https://threatenedtaxa.org/index.php/JoTT/aims_scope
For Article Submission Guidelines, visit https://threatenedtaxa.org/index.php/JoTT/about/submissions
For Policies against Scientific Misconduct, visit https://threatenedtaxa.org/index.php/JoTT/policies_various

continued on the back inside cover 


\title{
Comparison of bird diversity in protected and non-protected wetlands of western lowland of Nepal
}

\author{
Jagan Nath Adhikari ${ }^{1}$ (D), Janak Raj Khatiwada ${ }^{2}$ (D), Dipendra Adhikari ${ }^{3}$ (D), Suman Sapkota ${ }^{4}$ (D), \\ Bishnu Prasad Bhattarai ${ }^{5}$ (D), Deepak Rijal ${ }^{6}$ (D) \& Lila Nath Sharma ${ }^{7}$ (D) \\ ${ }^{1,5}$ Central Department of Zoology, Institute of Science and Technology, Tribhuvan University, Kathmandu, Nepal. \\ ${ }^{1}$ Department of Zoology, Birendra Multiple Campus, Bharatpur, Chitwan, Nepal. \\ ${ }^{2}$ Chengdu Institute of Biology, Chinese Academy of Sciences, Chengdu 610041, China. \\ ${ }^{3}$ Small Mammals Conservation and Research Foundation, PO Box 9092, Kathmandu, Nepal. \\ ${ }^{4}$ Friends of Nature (FON), Kathmandu, Nepal. \\ ${ }^{6}$ USAID Program for Aquatic Natural Resource Improvement, Paani Program, Baluwatar, Kathmandu, Nepal. \\ ${ }^{7}$ Forest Action Nepal, Bagdol Lalitpur, Nepal. \\ ${ }^{1}$ jagan.adhikari@bimc.tu.edu.np (corresponding author), ${ }^{2}$ janakrajkhatiwada@gmail.com, ${ }^{3}$ dipenadk2005@gmail.com, \\ ${ }^{4}$ suman.palpa99.ss@gmail.com, ${ }^{5}$ bishnu.bhattarai@cdz.tu.edu.np, ${ }^{6}$ deepak_rijal@dai.com, ${ }^{7}$ lilanathsharma@gmail.com
}

\begin{abstract}
Protected areas are considered important for biodiversity conservation, however, studies have shown that habitats outside protected areas can also support high diversity and are important for biodiversity conservation. In this context, we compared the bird diversity between protected (Rani Taal in Shuklaphanta National Park) and non-protected (Sati Karnali Taal) wetlands in western Nepal. Bird surveys were conducted from February to August 2019, using open width point count method in $100 \mathrm{~m}$ intervals along transects. A total of 122 species belonging to 18 orders and 44 families were recorded from the protected wetland, and 107 species belonging to 16 orders and 41 families from the non-protected wetland area. Insectivores had high abundance in both wetlands (43\% and $47 \%$ in protected and non-protected wetlands, respectively). Forest-dependent birds were more abundant in protected wetland compared to non-protected wetland. Our study showed that both protected and non-protected wetlands along with agricultural landscapes, support a richness of birds. Hence priority should be given to both wetlands for the conservation of birds.
\end{abstract}

Keywords: Aves, conservation, protected and non-protected areas, threatened birds.

Citation: Adhikari, J.N., J.R. Khatiwada, D. Adhikari, S. Sapkota, B.P. Bhattarai, D. Rijal \& L.N. Sharma (2022).Comparison of bird diversity in protected and nonprotected wetlands of western lowland of Nepal. Journal of Threatened Taxa 14(1): 20371-20386. https://doi.org/10.11609/jott.7452.14.1.20371-20386

Copyright: (c) Adhikari et al. 2022. Creative Commons Attribution 4.0 International License. JoTT allows unrestricted use, reproduction, and distribution of this article in any medium by providing adequate credit to the author(s) and the source of publication.

Funding: This work was supported by USAID funded Paani Program (G-KAT-041) and ForestAction Nepal.

Competing interests: The authors declare no competing interests.

Author details \& Author contributions: See end of this article.

Acknowledgements: Authors thank the Department of National Parks and Wildlife Conservation (DNPWC), Shuklaphanta National Park; Department of Forest and Division Forest Office Kailali for granting permission and support to conduct this research; USAID funded Paani Program for supporting this study (G-KAT-041); Forest Action Nepal for providing support, Sati Karnali Community Forest user groups, local communities of the Sati Karnali area for their support in the study area.
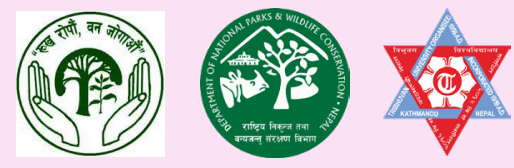


\section{INTRODUCTION}

Protected area (PA) is a key strategy for in situ conservation of biodiversity. Evidence has shown PAs that are crucial in conserving forests, natural environments, biodiversity, and ecosystem services (Rodrigues et al. 2004; Dahal et al. 2014; Watson et al. 2016). In the past, PAs surged globally, and Nepal has also made notable progress in increasing PA coverage (UNEP-WCMC et al. 2018; DNPWC 2020). By the end of 2020 over $15 \%$ of the earth's terrestrial surface was covered by PAs (Terborgh et al. 2002; UNEP-WCMC et al. 2018). In spite of increase in PAs, their efficacy in protecting overall biodiversity is contested (Rodrigues et al. 2004; Chape et al. 2005). Several important species remain outside the jurisdiction of PAs (Chakravarty et al. 2012), and some geographical areas are under-represented (Shrestha et al. 2010), incuding some global biodiversity hotspots and agro-ecosystems that support rich biodiversity (Sharma \& Vetaas 2015). Researchers have argued and demonstrated that areas outside formal PAs are worth conserving, as they provide alternative habitats and refuges for maintaining viable populations of residential and migratory bird species (Shrestha et al. 2010; Cox \& Underwood 2011; Dudley et al. 2014; DNPWC 2020) and thus complement PAs in achieving biodiversity goals.

Freshwater ecosystems are among the most productive ecosystems, and they provide countless services to both the human and ecological communities (Dudgeon et al. 2006). Yet they remain vulnerable to various stresses and pressures (Geist 2011). Freshwater constitutes about $2.5 \%$ of the area of all water on Earth (Ostfeld et al. 2012) and approximately 5\% (743,500 ha) in Nepal (Siwakoti \& Karki 2009). In the global context, wetlands support more than $40 \%$ of the birds and $12 \%$ of other animals (Kumar 2005; Paracuellos 2006). More than $20 \%$ of threatened bird species, both migratory and resident, are supported by the wetlands of Asia (Paracuellos 2006; Grimmett et al. 2016a).

Birds are important indicators of the health of freshwater ecosystems (Zakaria \& Rajpar 2010; Inskipp et al. 2017; Baral \& Inskipp 2020; Brotherton et al. 2020). Past studies have highlighted that Nepal's freshwater diversity has been threatened by different factors, including construction of dams, point source and non-point source pollution, habitat encroachment by invasive species, overharvesting, and recent global environmental changes (Khatiwada et al. 2021).

Many wetlands outside protected areas are important for conserving biodiversity, but are not given due attention for conservation. Past studies of bird species have been mostly concentrated in the protected areas and Ramsar sites. The difference in bird diversity between protected and non-protected areas is not well documented. In this study, we compared bird diversity between wetlands within a PA (Rani Taal in Shuklaphanta National Park) and outside it (Sati Karnali Taal), and asked following questions: (i) is there a difference in bird richness between protected and non-protected wetlands? (ii) is there a difference in conservation value for birds inside and outside protected area? (iii) do birds in protected and non-protected wetland differ in their feeding guilds? Understanding the distribution of bird diversity in and outside PAs can be useful to conservation managers and planners to formulate conservation strategies.

\section{MATERIALS AND METHODS}

\section{Study area}

This study was conducted in two wetlands, one in Shuklaphanta National Park (Rani Taal, hereafter referred to as protected and undisturbed wetland) and one in a nearby agricultural landscape (Sati Karnali Taal, hereafter non-protected and disturbed wetland), selected to compare bird diversity and distribution (Image 1). These wetlands share similar geography and climatic conditions, but differ in terms of management and disturbance (Table 1).

\section{Bird survey}

A bird survey was carried out following the "point count" method along transects near the bank of lake/ wetland, following detailed instructions provided by Bibby et al. (2000) from February to September 2019 two times a day at 0600-1000 h and 1600-1800 h. A total of five transects were laid in each wetland and bird study was carried out during the winter and summer seasons. The length of the transect walks varied from $500 \mathrm{~m}$ to $1,000 \mathrm{~m}$ depending upon the shape of the wetland and forest patch. The points were fixed in every 100-m intervals along the transects, then the birds were scanned and counted with the aid of binoculars (Nikon $20 \times 50$ and Bushnell $10 \times 40$ ) within the $50 \mathrm{~m}$ circular radius.

Four observers scanned for birds in all directions for five minutes. The observed birds were counted and listed, and data from all observers were pooled for each transect. To ensure a comprehensive species list for each survey site, calls of birds were also recorded with a cell phone in MP3 format. All the observed species were 

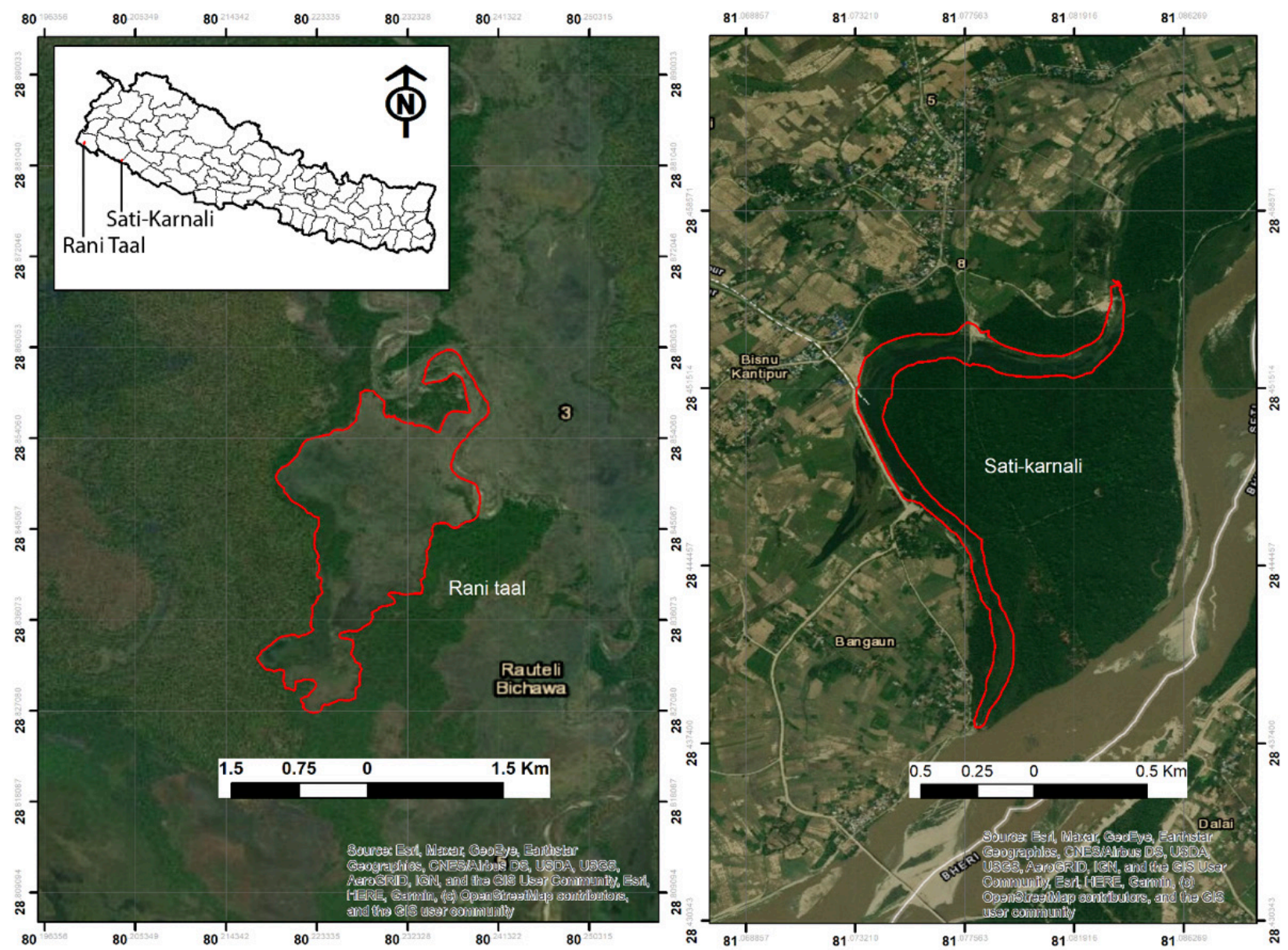

Figure 1. Map of the study area showing protected and non-protected wetlands.

recorded with abundance by visual and auditory aids, with habitat and environmental variables. Birds were identified using Grimmett et al. (2016a,b). Calls were identified using the bird song database of Xeno-Canto (https://www.xeno-canto.org/). Foraging behavior was grouped into five different trophic structures based on the feeding habit of birds and availability of food resources in the study area (Zakaria \& Rajpar 2010). These trophic structures are: insectivores, omnivores, piscivores, herbivores, and carnivores. We also carried out a questionnaire survey and literature review to record migratory and other rare bird species in the area.

\section{Data analysis}

We classified birds based on their feeding guilds, habitats and migratory behavior (BCN \& DNPWC 2016; Grimmett et al. 2016). We also categorized bird conservation status using IUCN Red List (https://www. iucnredlist.org). Species richness refers to the number of species, and abundance means the number of individuals of each species. We used two measures of richness, one for transects and another for sites. We also calculated the diversity indices of birds in protected and non-protected sites.

Shannon Weiner diversity index $(\mathrm{H})$ was used to determine species diversity in a community (Shannon 1948).

$$
\text { Shannon index }(\mathrm{H})=\frac{1}{\sum_{i=1}^{S} p_{i}^{2}}
$$

Where, $p_{i}$ is the proportion $(n / N)$ of individuals of one particular species found $(n)$ divided by the total number of individuals found $(N), \ln$ is the natural $\log , \Sigma$ is the sum of the calculations, and $\mathrm{s}$ is the number of species.

Simpson index was determined to measure community diversity in relation to habitats (Simpson 1949).

Simpson index (D) $=-\sum_{i=1}^{s} p_{i} \ln p_{i}$

Where $p$ is the proportion $(n / N)$ of individuals of one particular species found ( $n$ ) divided by the total number of individuals found ( $N), \Sigma$ is the sum of the calculations, and $s$ is the number of species.

Evenness (e) was used to determine distribution of 
individuals of a species in a community.

Evenness $=\mathrm{H}^{\prime} / \mathrm{Hmax}$

Where $\mathrm{H}^{\prime}$ is Shannon diversity index and Hmax is the maximum possible value. $E$ is constrained between 0 and 1.0. As with $\mathrm{H}^{\prime}$, evenness assumes that all species are represented within the sample.

Jacob's equitability $(\mathrm{J})$ was used to measure the evenness with which individuals are divided among the taxa present. Equitability $(\mathrm{J})=\mathrm{H}^{\prime} / \ln \mathrm{S}$

Where, $\mathrm{H}^{\prime}$ = Shannon's index of diversity, $\mathrm{S}=$ number of taxa

Fisher's index describes mathematically the relation between the number of species and the number of individuals in those species (Fisher \& Yates 1943). Fisher diversity index, defined implicitly by the formula.

$$
\mathrm{S}=\mathrm{a} \times \ln \left(1+\frac{\mathrm{n}}{\mathrm{a}}\right)
$$

Where, $\mathrm{S}$ is number of taxa, $\mathrm{n}$ is number of individuals and $a$ is the Fisher's alpha.

Differences in species richness and abundance between the protected and non-protected areas were tested using a student $t$ test. Data were checked for normality before conducting the $t$ test. All statistical analyses were carried out in $R$ version. 3.6.1 ( $R$ Development Core Team 2019).

\section{RESULTS}

Diversity and distribution of birds in protected and non-protected wetlands

We recorded a total of 1,693 individuals (winter= 961; summer $=732$ ) belonging to 122 species (winter= 118; summer $=104$ ) from 18 orders and 44 families in the protected wetland, and 1,672 individuals (winter= 791 ; summer $=881$ ) belonging to 107 species (winter= 94; summer $=86$ ) from 16 orders and 41 families in nonprotected wetland (Appendix 1). The most abundant species were from order Passeriformes (37\%) followed by Coraciiformes (9.8\%), Psittaciformes (7.2\%), and Galliformes $(6.3 \%)$ in the protected wetland whereas Passeriformes (43\%) was the most abundant followed by Coraciiformes (11\%), Pelecaniformes $(6.9 \%)$, and Psittaciformes (6.8\%) in the non-protected wetland.

In terms of cumulative abundance, Common Peafowl (4.9\%) was the most abundant species in the protected wetland, followed by House Swift (4.7\%), Blue-tailed Beeeater $(4.3 \%)$, and Wire-tailed Swallow (3.0\%), whereas House Sparrow (4.2\%) was the most abundant species followed by Cattle Egret (4.0\%), Blue-tailed Bee-eater (3.5\%), Lesser Whistling Duck (3.3\%), and Slaty-headed
Parakeet (3.2\%) in non-protected wetland (Appendix 1).

Overall, there was higher richness of birds in protected wetland $(\mathrm{n}=122$ compared to non-protected wetland ( $n=107, t=8.623, p<0.004)$. Similarly, species richness was also higher in both summer $(t=4.01, p=$ 0.004 ) and winter ( $t=4.726, p=0.001)$ seasons (Figure 1 ) in protected wetland. However, there was no significant difference in species abundance between protected and non-protected wetlands $(t=0.140, p=0.870)$. But the mean abundance of the birds was higher in summer season than winter in protected wetland (Figure 1).

The overall Shannon index of diversity $(\mathrm{H})$, and Fisher alpha $(\alpha)$ in protected wetland was higher than from the non-protected wetland (Table 2). Similarly, the species diversity of protected wetland was more in winter season than summer. But there was no variation in species dominance index (D) during winter and summer seasons $(D=0.019$, in winter and $D=0.021$, in summer season) (Table 2). Similarly, the species diversity of birds in non-protected wetland was more winter $(\mathrm{H}=4.21, \alpha=$ 31.0) than in summer $(H=4.19, \alpha=27.43$ ) (Table 2$)$.

\section{Categorization of birds according to habitat types}

A total of 49 species of wetland dependent birds, followed by 43 species of forest, 17 species of open area birds, and 13 species of bush birds were recorded from protected wetland, whereas 41 species of wetland birds, 37 species of forest birds, 18 species of open area birds, and 11 species of bush dependent birds were recorded from human dominated non-protected lake (Figure 2).

\section{Feeding guilds of birds}

The proportion of insectivorous birds was higher in both wetlands (protected $43.5 \%$ and non-protected $47.41 \%$ ) followed by omnivores, piscivores, herbivores, and carnivores, respectively (Figure 3 ).

\section{Bird species with conservation concern}

We recorded a globally Endangered species: Egyptian Vulture Neophron percnopterus; two Vulnerable species: Common Pochard Aythya ferina \& Great Slaty Woodpecker Mulleripicus pulverulentus; and seven Near Threatened species: Grey-headed Fish Eagle Icthyophaga ichthyaetus, Lesser Fish Eagle Icthyophaga humilis, River Lapwing Vanellus duvaucelii, Redheaded Falcon Falco chicquera, Painted Stork Mycteria leucocephala, Asian Woollyneck Ciconia episcopus, \& Oriental Darter Anhinga melanogaster in protected wetland. In non-protected wetland and its vicinity we reported three Vulnerable species: Common Pochard Aythya ferina, Great Slaty Woodpecker Mulleripicus 
Table 1. Comparative information about the study area: Protected and non-protected wetlands of lowland Terai western Nepal.

\begin{tabular}{|c|c|c|}
\hline Parameters & Protected wetland & Non-protected wetland \\
\hline Location & Inside Shuklaphanta National Park, Kanchanpur & Inside Sati Karnali Community Forest User Group, Tikapur, Kailali \\
\hline Geographic location & N28.922883/E80.176317 & N28.453533/ E81.07378 \\
\hline Elevation & $175 \mathrm{~m}$ & $158 \mathrm{~m}$ \\
\hline River basin & Mahakali & Karnali \\
\hline Nature of lake & Oxbow & Oxbow \\
\hline Area & 369 hector & 25 hector \\
\hline Temperature & $\begin{array}{l}\text { Average temperature } 25.9^{\circ} \mathrm{C}\left(14.3-32^{\circ} \mathrm{C} \text {, warmest month May }\right. \\
\text { and coldest month January) }\end{array}$ & $\begin{array}{l}\text { Average temperature } 24.6^{\circ} \mathrm{C}\left(15.6-32{ }^{\circ} \mathrm{C} \text {, warmest month May }\right. \\
\text { and coldest month January) }\end{array}$ \\
\hline Rainfall & $1,579 \mathrm{~mm}$ & $1,757 \mathrm{~mm}$ \\
\hline Feeder & Rainwater & Rani Kulo \\
\hline Vegetation & $\begin{array}{l}\text { Surrounded by dense Sal (Shorea robusta) forest. Associated } \\
\text { tree species are Kusum (Scheleira oleosa), Saaj (Terminalia } \\
\text { alata), Rohini (Mallotus phillipensis), Jamun (Syzygium cuminii), } \\
\text { Bhellar (Trewia nudiflora) Common shrub species: Rudilo } \\
\text { (Pogostemon bengalensis), Asare (Murraya koenighii) and } \\
\text { Bhati (Clerodendrum viscosum). The lake is surrounded by } \\
\text { elephant grass (Saccharum spontaneum), Narenga (Narenga } \\
\text { porphyrocoma) on south, west and east Khatiwada et al. (2019) }\end{array}$ & $\begin{array}{l}\text { Surrounded by riverine type and dominated by Sissoo } \\
\text { (Dalbergia sissoo), Simal (Bombax ceiba), Vellar (Trewia } \\
\text { nudiflora) and Khayer (Acacia catechu). Sindhure (Mallotus } \\
\text { phillipensis) and Shirish (Albizia chinensis) Common shrub } \\
\text { species: Asare (Murraya keonighii), Bhati (Clerodendron } \\
\text { viscosum). This area is well known for rattan cane (Calamus } \\
\text { tenuis). Khatiwada et al. (2019) }\end{array}$ \\
\hline Disturbance & $\begin{array}{l}\text { No human impact, Natural eutrophication and siltation is } \\
\text { common. More than } 80 \% \text { of the total area of this lake is } \\
\text { converted into grassland and marshy land }\end{array}$ & $\begin{array}{l}\text { Anthropogenic activities such as fishing, collection of snails, } \\
\text { other aquatic products, grazing are very common. }\end{array}$ \\
\hline Management authority & Shuklaphanta National Park & Sati Karnali Community Forest User Group \\
\hline
\end{tabular}

Table 2. The diversity and dominance indices of birds in protected and non-protected wetlands.

\begin{tabular}{|l|c|c|c|c|c|c|}
\hline \multirow{2}{*}{} & \multicolumn{2}{|c|}{ Winter } & \multicolumn{2}{c|}{ Summer } & \multicolumn{2}{c|}{ Total } \\
\cline { 2 - 7 } & Protected & Non-protected & Protected & Non-protected & Protected & 122 \\
\hline Species richness & 118 & 94 & 0.021 & 0.03 & 0.019 \\
\hline Dominance_D & 0.019 & 0.03 & 4.29 & 4.19 & 4.47 \\
\hline Shannon_H & 4.512 & 4.21 & 0.69 & 0.67 & 0.66 \\
\hline Evennes__e^H/S & 0.68 & 0.69 & 0.921 & 0.92 & 0.672 \\
\hline Equitability_J & 0.917 & 0.921 & 34.51 & 27.43 & 0.921 \\
\hline Fisher_alpha & 37.21 & 31 & 27.31 & 31.54 \\
\hline
\end{tabular}

pulverulentus, \& Lesser Adjutant Leptoptilos javanicus; and six Near Threatened species: Grey-headed Fisheagle Icthyophaga ichthyaetus, River Lapwing Vanellus duvaucelii, Asian Woollyneck Ciconia episcopus, Painted Stork Mycteria leucocephala, Oriental Darter Anhinga melanogaster, and Alexandrine Parakeet Psittacula eupatria (Figure 4, Image 2).

\section{DISCUSSION}

The present study examined diversity of wetlandassociated bird species from the lowlands of western Nepal. Our results indicate that bird community structure (i.e., species richness, abundance, composition) varied notably between protected and non-protected wetland and associated areas. Nevertheless, wetlands outside the protected area system also support a large number of important birds.

\section{Bird diversity in protected and non-protected areas}

The wetlands in both protected and non-protected areas support a considerable bird diversity of different feeding guilds. Overall, higher bird diversity was found in protected areas, signifying the importance of these areas for species conservation. Similar results were reported by Dahal et al. (2014) from forests of lowland Nepal. Abundance of forest specialist bird species such as Lesser Yellownape Picus chlorolophus and Common Peafowl Pavo cristatus was higher around the protected 


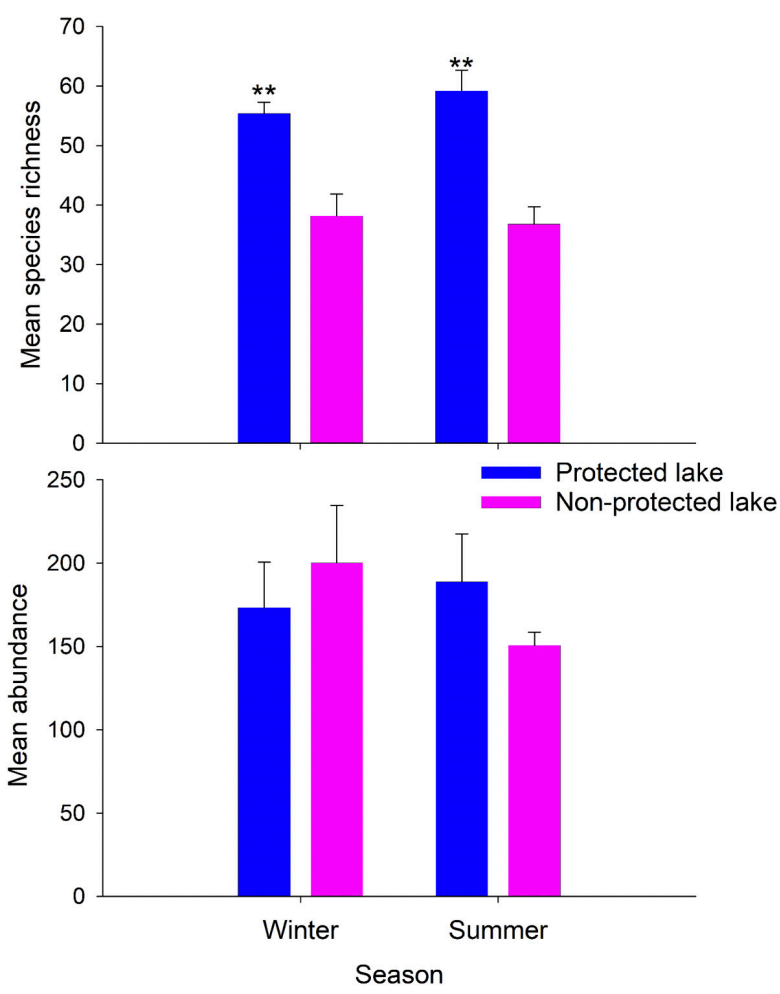

Figure 1. Mean richness and abundance of bird species on the protected and non-protected wetlands. The level of significance is from t-test $(* *<0.01)$.

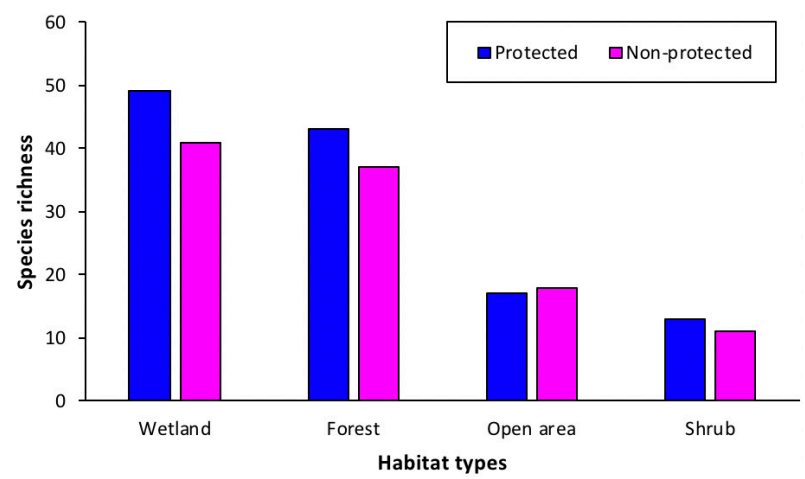

Figure 2. Habitat-wise species richness of birds.

wetland compared to non-protected wetland and surrounding areas (Appendix 1).

Our results showed an important dynamic in the wetlands in and outside the protected area. Increasing in richness in PA within the wetlands during summer, there is not distinct change in wetlands outside the PA (Figure 1). Slight increase of bird richness inside the PA might be because it provides a safe refuge for breeding birds and the disturbance is very low. Similarly, the higher abundance of the birds outside the PA during

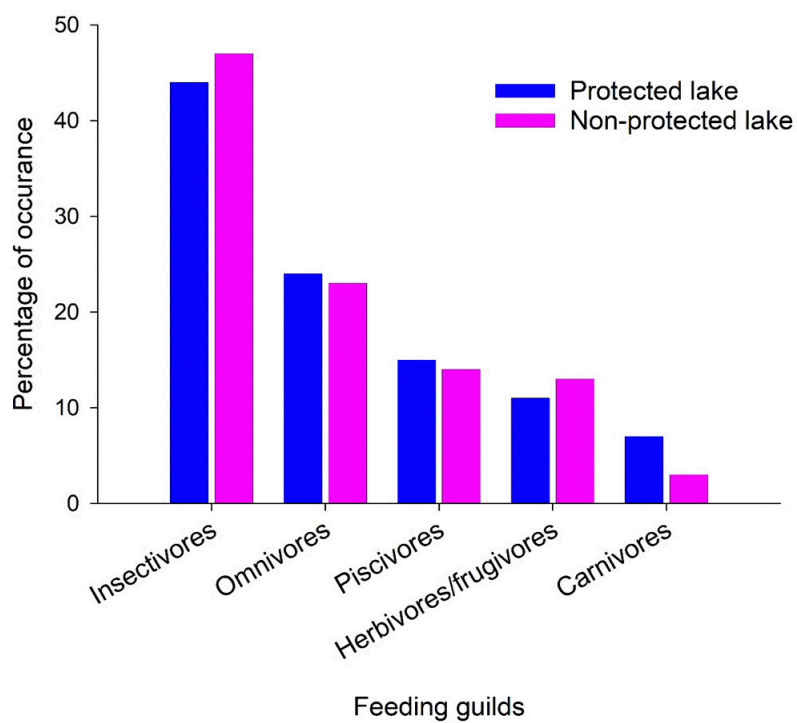

Figure 3. Percentage of bird species recorded for the different feeding guilds.

winter indicates that open and more disturbed nature of the wetlands are equally important to provide habitat for birds. Agriculture landscapes around the wetlands outside the protected area also provide bird feeding grounds. Abundance in wetlands outside PA decreases noticeably, indicating that winter migrants would have left and some resident species may also leave seeking safer habitat to breed. During MarchJune, water resources inside the PA become dry and the birds concentrate in this lake, hence it shows greater abundance during summer than in winter.

Our study reports higher species richness in wetland followed by forest birds (Figure 2). The species richness of birds is comparatively higher in and around the protected wetland. Lowland protected areas support old and mature forests and harbor the highest richness of forest specialist bird species (Dahal et al. 2014). Similarly, some of the wetland-dependent and associated bird species like Lesser Fish Eagle Icthyophaga humilis, Osprey Pandion haliaetus, Mallard Anas platyrhynchos, Ruddy Shelduck Tadorna ferruginea, and Gadwall Mareca strepera were reported only from the protected wetland and associated areas. Higher richness of birds in protected wetland areas may be attributed to lower anthropogenic disturbance (Khatri et al. 2019; Lamsal et al. 2019), supporting birds that require undisturbed forests.

National Park are surrounded by Sal forest and grassland that support many globally threatened birds. Nepal's wetlands provide an important habitat for many wetland dependent and grassland birds including 15 

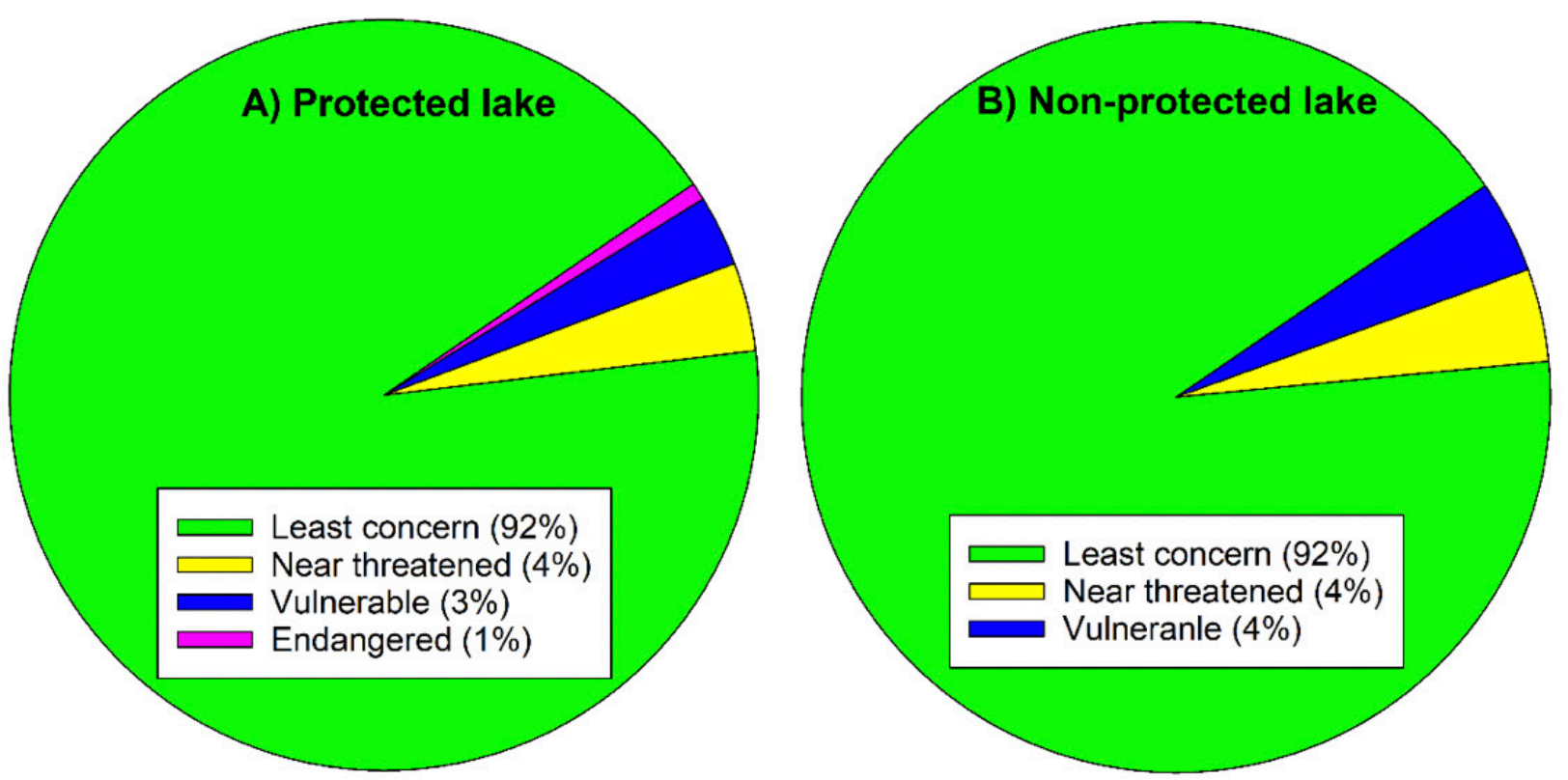

Figure 4. Pie chart showing the percentage of bird species according to IUCN Category.

globally threatened and 13 near threatened bird species (Baral \& Inskipp 2009). During our study, we recorded one Endangered species of bird: Egyptian Vulture Neophron percnopterus, two globally Vulnerable birds: Great Slaty Woodpecker Mulleripicus pulverulentus Common Pochard Aythya ferina and five globally Near Threatened birds in and around the protected lake.

Habitat heterogeneity is greater inside the Shuklaphanta National Park in and around the protected wetland. Higher the habitat heterogeneity favours higher the species diversity (Tamme et al. 2010). Hence higher number of forest specific birds and wetland birds were recorded in the protected wetland. But the non-protected wetland is surrounded by small patch of forest and agriculture landscape. The exploitation of natural resources and impact of human pressure was more in non-protected wetland which may be a cause of lower abundance of forest and wetland specialist birds. Nevertheless, due to diverse habitats, agricultural landscape supported higher richness and abundance of open area birds. Elsen et al. (2017) reported that low intensity agriculture supports higher bird diversity during winter in Himalayan montane landscape.

The wetland outside the protected area also supported considerable bird diversity. The birds reported here included several species listed as Vulnerable (VU) in IUCN Red List. Non-protected wetland and adjoining areas provide the suitable habitats for several vulnerable and near threatened bird species. During this study, we reported three Vulnerable and six Near Threatened bird species. The adjoining area of this wetland is surrounded by paddy fields and swampy areas, which are the foraging ground to several species (de Silva et al. 2015; Adhikari et al. 2019). The tree species present in paddy field and adjoining community forest provide the nesting and foraging places for birds. The study on the responses of birds with tree species in agricultural landscape found larger population sizes of birds with low intensity farming as they share same land for foraging (Hulme et al. 2013). Hence, land sharing would result in better bird conservation outcomes (Hulme et al. 2013; Edwards et al. 2014; Schulte et al. 2016) but land sparing has greater potential biodiversity benefits for large mammals, cats and large birds than land sharing (Lamb et al. 2019; Finch et al. 2020). Several studies show that agricultural land is an important driver that effect the wild nature directly or indirectly which is very common in developing countries (Green et al. 2005; Haslem \& Bennett 2008; Šálek et al. 2018; Chaudhary et al. 2020).

\section{Difference in feeding guilds}

The results showed that wetlands are suitable for avifauna as they offer shelter, food, suitable nesting, and roosting sites for different groups of birds (Giosa et al. 2018). The habitat preference of the bird could be due to the availability of food they feed on such as insects, fishes, frogs, lizards, mouse, grains, fruits, vegetable matter (Katuwal et al. 2016; Harisha \& Hosetti 2018). We identified five different foraging guilds such as insectivores, omnivores, piscivores, herbivores, and 


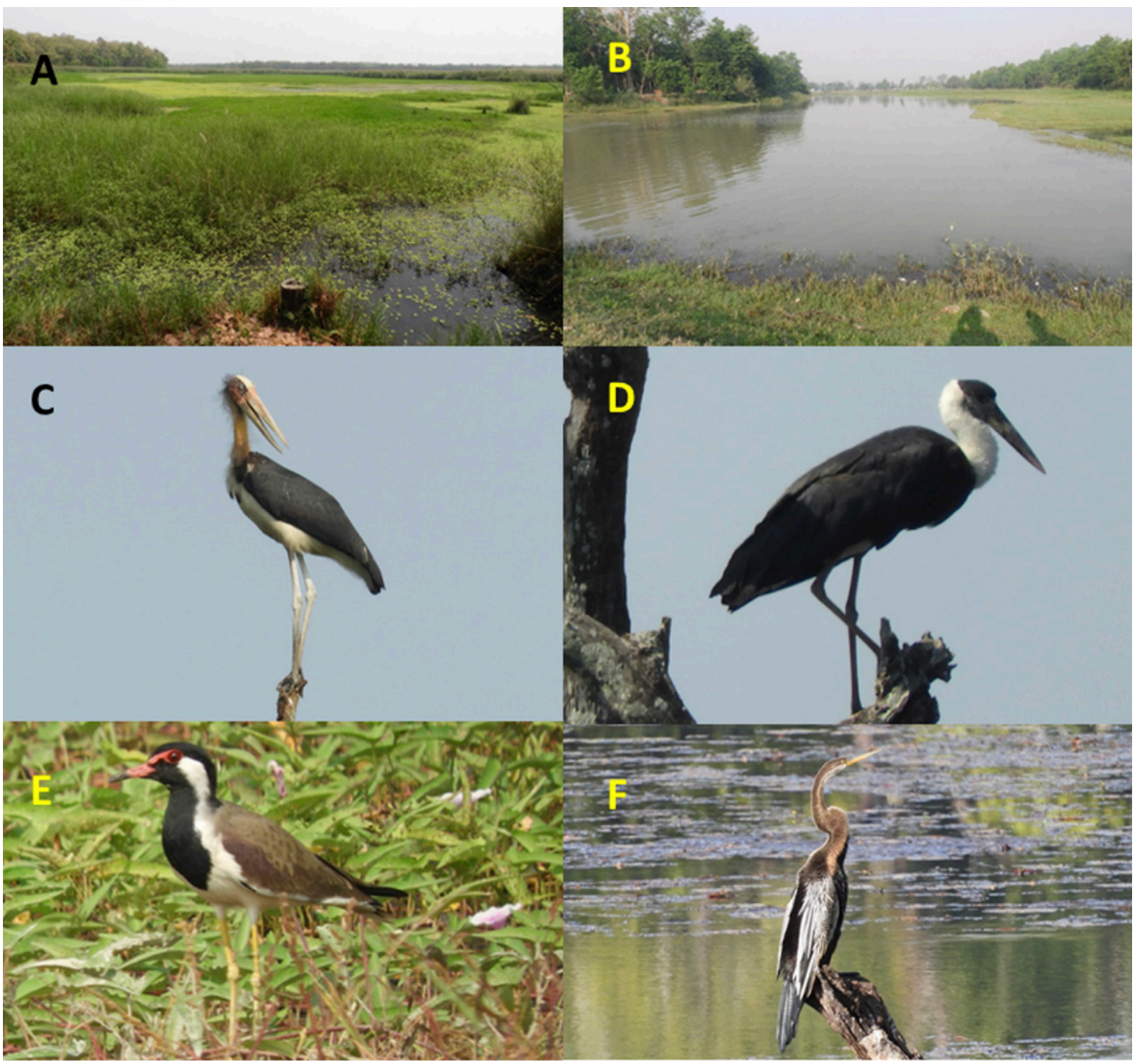

Image 2. A-protected wetland (Rani Taal) inside the Shuklaphanta National Park, western Nepal | B-non-protected wetland (Sati Karnali Taal) of Kailali district | C-Lesser Adjutant (Leptoptilos javanicus), globally Vulnerable, recorded from non-protected wetland | D-Asian Woolly-neck (Ciconia episcopus), globally Near threatened, recorded from both wetlands | E-Red-wattled Lapwing (Vanellus indicus), globally Least Concern, recorded from both wetlands | F-Oriental Darter (Anhinga melanogaster), globally near threatened recorded from both wetlands. () Jagan Nath Adhikari

carnivores of birds. Among them, insectivores were highly abundant in both wetland systems. Dahal et al. (2014) identified seven main foraging guilds of birds. Insectivores are the most dominant group of birds as compared to other birds in the globe (Zakaria \& Rajpar 2010; Datta 2011; Dahal et al. 2014; Basnet et al. 2016; Adhikari et al. 2018a,b). The main reason for the selection of different habitats by birds could be the presence of different vegetation types. The vegetation surrounding the protected wetland was dense and relatively mature compared to non-protected wetland.
The agricultural fields around the non-protected wetland also supported more insectivore birds. Hence, both protected and non-protected wetlands are very important from conservation aspects of birds.

\section{CONCLUSION}

This study demonstrates that both protected and non-protected wetlands have comparable richness, though the composition of birds slightly differed. 
Protected areas supported some forest and wetland specialist birds. The study reported the same common bird species on both protected and non-protected wetlands, hence, wetlands outside protected areas are also important for species conservation. This result suggests that the habitats outside protected areas also play an important complementary role to conservation of bird species which are worth conserving. Mosaics of habitat patches in low-intensity agricultural landscape favored considerable bird diversity which supports the idea that food production and biodiversity conservation can be reconciled in same landscape unit. Wetlands rich in biodiversity and sources of ecosystem goods and services are dwindling faster due to increased human activities related with agriculture, land use change and infrastructure development. We underscore call for action to extend program for the protection of ecosystem outside protected areas while emphasizing the management of protected areas for enhanced in situ conservation.

\section{REFERENCES}

Adhikari, J.N., B.P. Bhattarai \& D.N. Dhakal (2018a). Conservation value of Beeshhazari Lake: an insight into diversity and abundance of wetland birds. Our Nature 16(1): 17-26. https://doi.org/10.3126/ on.v16i1.21563

Adhikari, J.N., B.P. Bhattarai \& T.B. Thapa (2018b). Diversity and conservation threats of water birds in and around Barandabhar corridor forest, Chitwan, Nepal. Journal of Natural History Mesuem 30: 164-179. https://doi.org/10.3126/jnhm.v30i0.27553

Adhikari, J.N., B.P. Bhattarai \& T.B. Thapa (2019). Factors affecting diversity and distribution of threatened birds in Chitwan National Park, Nepal. Journal of Threatened Taxa 11(5): 13511-13522. https://doi.org/10.11609/jott.4137.11.5.13511-13522

Baral, H.S. \& C. Inskipp (2009). The birds of Suklaphanta Wildlife Reserve, Nepal. Our Nature 7(1): 56-81. https://doi.org/10.3126/ on.v7i1.2554

Baral, H.S. \& C. Inskipp (2020). Birds of Nepal: Their Status and Conservation Especially with Regards to Watershed Perspectives, pp. 435-458. In: Regmi, G.R. \& F. Huettmann (eds.). Hindu Kush-Himalaya Watersheds Downhill: Landscape Ecology and Conservation Perspectives. Springer. https://doi.org/10.1007/9783-030-36275-1_22

Basnet, T.B., M.B. Rokaya, B.P. Bhattarai \& Z. Munzbergova (2016). Heterogeneous Landscapes on Steep Slopes at Low Altitudes as Hotspots of Bird Diversity in a Hilly Region of Nepal in the Central Himalayas. PLoS ONE 11(3): e0150498. https://doi.org/10.1371/ journal.pone.0150498

BCN \& DNPWC (2016). Birds of Nepal: An Official Checklist. Bird Conservation Nepal (BCN) and Department of National Parks and Wildlife Conservation (DNPWC), Kathmandu, Nepal, 40 pp.

Bibby, C.J., N.D. Burgess, D.A. Hill \& S. Mustoe (2000). Bird census techniques. Academic Press, Elsevier, 302 pp.

Brotherton, S., C.B. Joyce \& J.P. Scharlemann (2020). Global offtake of wild animals from wetlands: critical issues for fish and birds. Hydrobiologia 847: 1631-1649. https://doi.org/10.1007/s10750020-04188-z

Chakravarty, S., S. Ghosh, C. Suresh, A. Dey \& G. Shukla (2012).
Deforestation: causes, effects and control strategies, pp. 1-26. In: Shukla, G. (eds.). Global perspectives on sustainable forest management. Intech Rijeka, Croatia, 315 pp.

Chape, S., J. Harrison, M. Spalding \& I. Lysenko (2005). Measuring the extent and effectiveness of protected areas as an indicator for meeting global biodiversity targets. Philosophical Transactions of the Royal Society B: Biological Sciences 360(1454): 443-455. https:// doi.org/10.1098/rstb.2004.1592

Chaudhary, S., Y. Wang, A.M. Dixit, N.R. Khanal, P. Xu, B. Fu, K. Yan, Q. Liu, Y. Lu \& M. Li (2020). A synopsis of farmland abandonment and its driving factors in Nepal. Land 9(3): 1-24. https://doi. org/10.3390/land9030084

Cox, R.L. \& E.C. Underwood (2011). The importance of conserving biodiversity outside of protected areas in Mediterranean ecosystems. PLOS ONE 6(1): e14508. https://doi.org/10.1371/ journal.pone.0014508

Dahal, B.R., C.A. McAlpine \& M. Maron (2014). Bird conservation values of off-reserve forests in lowland Nepal. Forest Ecology and Management 323: 28-38. https://doi.org/10.1016/j. foreco.2014.03.033

Dahal, B.R., C.A. McAlpine \& M. Maron (2015). Impacts of extractive forest uses on bird assemblages vary with landscape context in lowland Nepal. Biological Conservation 186: 167-175. https://doi. org/10.1016/j.biocon.2015.03.014

Datta, T. (2011). Human interference and avifaunal diversity of two wetlands of Jalpaiguri, West Bengal, India. Journal of Threatened Taxa 3(12): 2253-2262. https://doi.org/10.11609/JoTT.o2739.225362

de Silva, T.N., S. Fernando, H.B. de Silva \& P. Tennakoon (2015). Lesser Adjutant Leptoptilos javanicus Horsfield, 1821 (Ciconiiformes: Ciconiidae) in the dry lowlands of Sri Lanka: distribution, ecology, and threats. Journal of Threatened Taxa 7(14): 8089-8095. https:// doi.org/10.11609/jott.2425.7.14.8089-8095

DNPWC (2020). Protected areas of Nepal. Department of National Parks and Wildlife Conservation (DNPWC) Nepal, Kathmandu, Nepal. Downloaded on 20 January 2020. http://www.dnpwc.gov.np

Dudgeon, D., A.H. Arthington, M.O. Gessner, Z.I. Kawabata, D.J. Knowler, C. Lévêque, R.J. Naiman, A.-H. Prieur-Richard, D. Soto \& M.L. Stiassny (2006). Freshwater biodiversity: importance, threats, status and conservation challenges. Biological Reviews 81(2): 163182. https://doi.org/10.1017/S1464793105006950

Dudley, N., C. Groves, K.H. Redford \& S. Stolton (2014). Where now for protected areas? Setting the stage for the 2014 World Parks Congress. Oryx 48(4): 496-503. https://doi.org/10.1017/ S0030605314000519

Edwards, D.P., J.J. Gilroy, P. Woodcock, F.A. Edwards, T.H. Larsen, D.J. Andrews, M.A. Derhe, T.D. Docherty, W.W. Hsu, S.L. Mitchell, T. Ota, L.J. Williams, W.F. Laurance, K.C. Hamer \& D.S. Wilcove (2014). Land-sharing versus land-sparing logging: reconciling timber extraction with biodiversity conservation. Globle Change Biology 20(1): 183-191. https://doi.org/10.1111/gcb.12353

Elsen, P.R., R. Kalyanaraman, K. Ramesh \& D.S. Wilcove (2017). The importance of agricultural lands for Himalayan birds in winter. Conservation Biology 31(2): 416-426. https://doi.org/10.1111/ cobi.12812

Finch, T., S. Gillings, D. Massimino, T. Brereton, J. Redhead, R. Pywell, R. Field, A. Balmford, R. Green \& W. Peach (2020). Assessing the utility of land sharing and land sparing for birds, butterflies and ecosystem services in lowland England. Natural England Commissioned Report NECR280, 73 pp.

Fisher, R.A. \& F. Yates (1943). Statistical Tables: For Biological, Agricultural and Medical Research. Second edition. Oliver and Boyd Ltd, London, 105 pp.

Geist, J. (2011). Integrative freshwater ecology and biodiversity conservation. Ecological Indicators 11(6): 1507-1516. https://doi. org/10.1016/j.ecolind.2011.04.002

Green, R.E., S.J. Cornell, J.P. Scharlemann \& A. Balmford (2005). Farming and the fate of wild nature. Science 307(5709): 550-555. http://doi.org/10.1126/science.1106049 
Grimmett, R., C. Inskipp \& T. Inskipp (2016a). Birds of the Indian Subcontinent: India, Pakistan, Sri Lanka, Nepal, Bhutan, Bangladesh and the Maldives. Bloomsbury Publishing, $448 \mathrm{pp}$.

Grimmett, R., C. Inskipp, T. Inskipp \& H.S. Baral (2016b). Birds of Nepal: Revised Edition. Bloomsbury Publishing, India, 386 pp.

Harisha, M.N. \& B.B. Hosetti (2018). Status and conservation issues of wetland birds in Komaranahalli lake, Davanagere district, Karnataka, India. Journal of Threatened Taxa 10(2): 11290-11294. http://doi. org/110.11609/jott.2809.10.2.11290-11294

Haslem, A. \& A.F. Bennett (2008). Birds in agricultural mosaics: the influence of landscape pattern and countryside heterogeneity. Ecological Applications 18(1): 185-196. https://doi org/10.1890/07-0692.1

Hulme, M.F., J.A. Vickery, R.E. Green, B. Phalan, D.E. Chamberlain, D.E. Pomeroy, D. Nalwanga, D. Mushabe, R. Katebaka \& S. Bolwig (2013). Conserving the birds of Uganda's banana-coffee arc: land sparing and land sharing compared. PLoS ONE 8(2): e54597. https:// doi.org/10.1371/journal.pone.0054597

Inskipp, C., H.S. Baral, T. Inskipp, A.P. Khatiwada, M.P. Khatiwada, L.P. Poudyal \& R. Amin (2017). Nepal's National Red List of birds. Journal of Threatened Taxa 9(1): 9700-9722. https://doi.org/10.11609/ jott.2855.9.1.9700-9722

Katuwal, H.B., K. Basnet, B. Khanal, S. Devkota, S.K. Rai, J.P. Gajurel, C. Scheidegger \& M.P. Nobis (2016). Seasonal Changes in Bird Species and Feeding Guilds along Elevational Gradients of the Central Himalayas, Nepal. PLOS ONE 11(7): e0158362. https://doi. org/10.1371/journal.pone.0158362

Khatiwada, J.R., J.N. Adhikari, D. Adhikari, S. Sapkota, S.R. Ghimire, P.B. Budha \& L.N. Sharma (2019). Assessment and conservation status of aquatic biodiversity in lower Karnali and Mahakali River basin. Forest Action Nepal, USAID Pani Program, 116 pp.

Khatiwada, J. R., J.N., Adhikari, D., Rijal \& L.N. Sharma (2021). Freshwater biodiversity in western Nepal: A review. Nepalese Journal of Zoology 5(1): 34-46. https://doi.org/10.3126/njz.v5i1.38290

Khatri, N.D., B. Neupane, Y.P. Timilsina \& S. Ghimire (2019). Assessment of Avifaunal diversity and threats to them in Phewa wetland, Nepal. Forestry: Journal of Institute of Forestry, Nepal 16: 31-47. https://doi.org/10.3126/forestry.v16i0.28352

Kumar, A. (2005). Handbook on Indian wetland birds and their conservation. Zoological Survey of India, Dehradun, India, $472 \mathrm{pp}$.

Lamb, A., T. Finch, J.W. Pearce-Higgins, M. Ausden, A. Balmford, C. Feniuk, G. Hirons, D. Massimino \& R.E. Green (2019). The consequences of land sparing for birds in the United Kingdom. Journal of Applied Ecology 56(8): 1870-1881. https://doi. org/10.1111/1365-2664.13362

Lamsal, P., K. Atreya, M.K. Ghosh \& K.P. Pant (2019). Effects of population, land cover change, and climatic variability on wetland resource degradation in a Ramsar listed Ghodaghodi Lake Complex, Nepal. Environmental Monitoring and Assessment 191(7): 1-16. https://doi.org/10.1007/s10661-019-7514-0

Ostfeld, A., S. Barchiesi, M. Bonte, C.R. Collier, K. Cross, G. Darch, T.A. Farrell, M. Smith, A. Vicory \& M. Weyand (2012). Climate change impacts on river basin and freshwater ecosystems: some observations on challenges and emerging solutions. Journal of Water and Climate Change 3(3): 171-184. https://doi.org/10.2166/ wcc. 2012.006
Paracuellos, M. (2006). Relationships of songbird occupation with habitat configuration and bird abundance in patchy reed beds. ARDEA 94(1): 87-98.

R Development Core Team (2019). A Language and Environment for Statistical Computing. R Foundation for Statistical Computing. R Foundation for Statistical Computing, Vienna, Austria.

Rodrigues, A.S., H.R. Akcakaya, S.J. Andelman, M.I. Bakarr, L. Boitani, T.M. Brooks, J.S. Chanson, L.D. Fishpool, G.A. Da Fonseca \& K.J. Gaston (2004). Global gap analysis: priority regions for expanding the global protected-area network. BioScience 54(12): 1092-1100. https://doi.org/10.1641/0006-3568(2004)054[1092:GGAPRF]2.0. $\mathrm{CO} ; 2$

Šálek, M., M. Bažant \& M. Żmihorski (2018). Active farmsteads are year-round strongholds for farmland birds. Journal of Applied Ecology 55(4): 1908-1918. https://doi.org/10.1111/13652664.13093

Schulte, L.A., A.L. MacDonald, J.B. Niemi \& M.J. Helmers (2016). Prairie strips as a mechanism to promote land sharing by birds in industrial agricultural landscapes. Agriculture, Ecosystems and Environment 220: 55-63. https://doi.org/10.1016/j.agee.2016.01.007

Shannon, C.E. (1948). Mathematical Theory of Communication. The Bell System Technical Journal 27(3): 379-424. https://doi. org/10.1002/j.1538-7305.1948.tb01338.x

Sharma, L.N. \& O.R. Vetaas (2015). Does agroforestry conserve trees? A comparison of tree species diversity between farmland and forest in mid-hills of central Himalaya. Biodiversity Conservation 24(8): 2047-2061. https://doi.org/10.1007/s10531-015-0927-3

Shrestha, U.B., S. Shrestha, P. Chaudhary \& R.P. Chaudhary (2010). How representative is the protected areas system of Nepal? Mountain Research and Development 30(3): 282-294. https://doi. org/10.1659/MRD-JOURNAL-D-10-00019.1

Simpson, E.H. (1949). Measurement of diversity. Nature 163(4148): 688-688. https://doi.org/10.1038/163688a0

Siwakoti, M. \& J.B. Karki (2009). Conservation status of Ramsar sites of Nepal Terai: an overview. Botanica Orientalis: Journal of Plant Science 6: 76-84. https://doi.org/10.3126/botor.v6i0.2914

Tamme, R., I. Hiiesalu, L. Laanisto, R. Szava-Kovats \& M. Pärtel (2010). Environmental heterogeneity, species diversity and co-existence at different spatial scales. Journal of Vegetation Science 21(4): 796801. https://doi.org/10.1111/j.1654-1103.2010.01185.x

Terborgh, J., C. van Schaik, L. Davenport \& M. Rao (2002). Making Parks Work: Strategies for Preserving Tropical Nature. Island Press, $511 \mathrm{pp}$.

UNEP-WCMC, IUCN \& NGS (2018). Protected Planet Report 2018. UNEP-WCMC, IUCN and NGS, Cambridge UK; Gland, Switzerland; and Washington, D.C., USA, $70 \mathrm{pp}$.

Watson, J.E., E.S. Darling, O. Venter, M. Maron, J. Walston, H.P. Possingham, N. Dudley, M. Hockings, M. Barnes \& T.M. Brooks (2016). Bolder science needed now for protected areas. Conservation Biology 30(2): 243-248. https://doi.org/10.1111/ cobi.12645

Zakaria, M. \& M.N. Rajpar (2010). Bird species composition and feeding guilds based on point count and mist netting methods at the Paya Indah Wetland Reserve, Peninsular Malaysia. Tropical Life Sciences Research 21(2): 7-26. 
Appendix 1. Bird species with their abundance observed in protected and non-protected wetlands in Winter and Summer. Relative abundance (RA) refers total percentage contribution of each species to the total sample. 0 indicated the species were not recorded during field study, here, $\mathrm{EN}=$ Endangered, $\mathrm{VU}=$ Vulnerable, $\mathrm{NT}=\mathrm{Near}$ threatened and $\mathrm{LC}=$ Least Concern.

\begin{tabular}{|c|c|c|c|c|c|c|c|c|c|}
\hline & \multirow[b]{2}{*}{$\begin{array}{l}\text { Order/Family/ } \\
\text { Common name }\end{array}$} & \multirow[b]{2}{*}{ Zoological name } & \multicolumn{2}{|c|}{ RA in Winter } & \multicolumn{2}{|c|}{ RA in Summer } & \multicolumn{2}{|c|}{ Total RA( \%) } & \multirow{2}{*}{$\begin{array}{l}\text { IUCN } \\
\text { category }\end{array}$} \\
\hline & & & Protected & $\begin{array}{c}\text { Non- } \\
\text { protected }\end{array}$ & Protected & $\begin{array}{c}\text { Non- } \\
\text { protected }\end{array}$ & Protected & $\begin{array}{c}\text { Non- } \\
\text { protected }\end{array}$ & \\
\hline \multicolumn{10}{|c|}{ Order ACCIPITRIFORMES } \\
\hline \multicolumn{10}{|c|}{ Family Accipitridae } \\
\hline 1 & Black Kite & Milvus migrans (Boddaert, 1783) & 0.004 & 0.5 & 0.007 & 0.554 & 0.524 & 0.53 & LC \\
\hline 2 & Crested Serpent-eagle & Spilornis cheela (Latham, 1790) & 0.002 & 0.125 & 0.001 & 0.111 & 0.175 & 0.117 & LC \\
\hline 3 & Grey-headed Fish-eagle & $\begin{array}{l}\text { Icthyophaga ichthyaetus } \\
\text { (Horsfield, 1821) }\end{array}$ & 0.002 & 0.503 & 0.001 & 0.443 & 0.175 & 0.47 & NT \\
\hline 4 & Lesser Fish-eagle & $\begin{array}{l}\text { Icthyophaga humilis (Müller \& } \\
\text { Schlegel, 1841) }\end{array}$ & 0.604 & 0 & 0.005 & 0 & 0.466 & 0 & NT \\
\hline 5 & Egyptian Vulture & $\begin{array}{l}\text { Neophron percnopterus } \\
\text { (Linnaeus, 1758) }\end{array}$ & 0.001 & 0 & 0.001 & 0 & 0.117 & 0 & EN \\
\hline \multicolumn{10}{|c|}{ Family Pandionidae } \\
\hline 6 & Osprey & \begin{tabular}{|l} 
Pandion haliaetus (Linnaeus, \\
1758)
\end{tabular} & 0.002 & 0 & 0.003 & 0 & 0.233 & 0 & LC \\
\hline \multicolumn{10}{|c|}{ Order ANSERIFORMES } \\
\hline \multicolumn{10}{|c|}{ Family Anatidae } \\
\hline 7 & Bar-headed Goose & Anser indicus (Latham, 1790) & 0.005 & 0 & 0 & 0 & 0.291 & 0 & LC \\
\hline 8 & Common Pochard & Aythya ferina (Linnaeus, 1758) & 1.915 & 1.509 & 0 & 0 & 0.874 & 0.707 & LC \\
\hline 9 & Common Shelduck & $\begin{array}{l}\text { Tadorna tadorna (Linnaeus, } \\
\text { 1758) }\end{array}$ & 1.017 & 1.509 & 0 & 0 & 0.932 & 0.7 & LC \\
\hline 10 & Common Teal & Anas crecca Linnaeus, 1758 & 0.004 & 0.628 & 0 & 0 & 0.233 & 0.294 & LC \\
\hline 11 & Gadwall & $\begin{array}{l}\text { Mareca strepera (Linnaeus, } \\
1758 \text { ) }\end{array}$ & 0.004 & 0 & 0 & 0 & 0.233 & 0 & LC \\
\hline 12 & Lesser Whistling-duck & $\begin{array}{l}\text { Dendrocygna javanica (Horsfield, } \\
\text { 1821) }\end{array}$ & 0.91 & 6.92 & 0 & 0 & 0.583 & 3.241 & LC \\
\hline 13 & Mallard & $\begin{array}{l}\text { Anas platyrhynchos Linnaeus, } \\
1758\end{array}$ & 0.002 & 0 & 0 & 0 & 0.117 & 0 & LC \\
\hline 14 & Ruddy Shelduck & Tadorna ferruginea (Pallas, 1764) & 0.002 & 0 & 0 & 0 & 0.117 & 0 & LC \\
\hline \multicolumn{10}{|c|}{ Order BUCEROTIFORMES } \\
\hline \multicolumn{10}{|c|}{ Family Bucerotidae } \\
\hline 15 & Indian Grey Hornbill & Ocyceros birostris (Scopoli, 1786) & 0.002 & 0 & 0.003 & 0.111 & 0.233 & 0.05 & LC \\
\hline \multicolumn{10}{|c|}{ Family Upupidae } \\
\hline 16 & Common Hoopoe & Upupa epops Linnaeus, 1758 & 0.006 & 0.25 & 0.008 & 0.222 & 0.699 & 0.235 & LC \\
\hline \multicolumn{10}{|c|}{ Order CAPRIMULGIFORMES } \\
\hline \multicolumn{10}{|c|}{ Family Apodidae } \\
\hline 17 & House Swift & Apus nipalensis (Hodgson, 1836) & 2.052 & 2.77 & 3.04 & 2.328 & 4.662 & 2.533 & LC \\
\hline \multicolumn{10}{|c|}{ Order CHARADRIIFORMES } \\
\hline \multicolumn{10}{|c|}{ Family Charadriidae } \\
\hline 18 & Grey-headed Lapwing & Vanellus cinereus (Blyth, 1842) & 0.004 & 0.251 & 0.005 & 0 & 0.466 & 0.118 & LC \\
\hline 19 & Red-wattled Lapwing & Vanellus indicus (Boddaert, 1783) & 0.004 & 0.503 & 0.007 & 0.665 & 0.524 & 0.589 & LC \\
\hline 20 & River Lapwing & $\begin{array}{l}\text { Vanellus duvaucelii (Lesson, } \\
\text { 1826) }\end{array}$ & 0.004 & 0.628 & 0.004 & 0.665 & 0.408 & 0.648 & NT \\
\hline 21 & Yellow-wattled Lapwing & $\begin{array}{l}\text { Vanellus malabaricus (Boddaert, } \\
1783 \text { ) }\end{array}$ & 0.004 & 1.006 & 0.005 & 1.219 & 0.466 & 1.119 & LC \\
\hline \multicolumn{10}{|c|}{ Family Jacanidae } \\
\hline 22 & Bronze-winged Jacana & $\begin{array}{l}\text { Metopidius indicus (Latham, } \\
1790 \text { ) }\end{array}$ & 0.81 & 0.628 & 1.019 & 0.332 & 1.399 & 0.471 & LC \\
\hline
\end{tabular}




\begin{tabular}{|c|c|c|c|c|c|c|c|c|c|}
\hline & \multirow[b]{2}{*}{$\begin{array}{l}\text { Order/Family/ } \\
\text { Common name }\end{array}$} & \multirow[b]{2}{*}{ Zoological name } & \multicolumn{2}{|c|}{ RA in Winter } & \multicolumn{2}{|c|}{ RA in Summer } & \multicolumn{2}{|c|}{ Total RA( \%) } & \multirow{2}{*}{$\begin{array}{l}\text { IUCN } \\
\text { category }\end{array}$} \\
\hline & & & Protected & $\begin{array}{c}\text { Non- } \\
\text { protected }\end{array}$ & Protected & $\begin{array}{c}\text { Non- } \\
\text { protected }\end{array}$ & Protected & $\begin{array}{c}\text { Non- } \\
\text { protected }\end{array}$ & \\
\hline \multicolumn{10}{|c|}{ Family Scolopacidae } \\
\hline 23 & Common Sandpiper & Actitis hypoleucos Linnaeus, 1758 & 0.004 & 0 & 0.003 & 0 & 0.35 & 0 & LC \\
\hline 24 & Green Sandpiper & Tringa ochropus Linnaeus, 1758 & 0.012 & 0.503 & 0.007 & 0.554 & 0.991 & 0.53 & LC \\
\hline 25 & Marsh Sandpiper & $\begin{array}{l}\text { Tringa stagnatilis (Bechstein, } \\
\text { 1803) }\end{array}$ & 0.004 & 0.503 & 0.003 & 0.443 & 0.35 & 0.471 & LC \\
\hline 26 & Wood Sandpiper & Tringa glareola Linnaeus, 1758 & 0.002 & 0 & 0 & 0 & 0.117 & 0 & LC \\
\hline \multicolumn{10}{|c|}{ Order CICONIIFORMES } \\
\hline \multicolumn{10}{|c|}{ Family Ciconiidae } \\
\hline 27 & Asian Openbill & $\begin{array}{l}\text { Anastomus oscitans (Boddaert, } \\
\text { 1783) }\end{array}$ & 0.71 & 1.509 & 0.009 & 1.77 & 0.991 & 1.649 & LC \\
\hline 28 & Asian Woollyneck & $\begin{array}{l}\text { Ciconia episcopus (Boddaert, } \\
\text { 1783) }\end{array}$ & 0.002 & 0.125 & 0.003 & 0.886 & 0.233 & 0.53 & NT \\
\hline 29 & Black Stork & Ciconia nigra (Linnaeus, 1758) & 0.002 & 0 & 0.003 & 0 & 0.233 & 0 & LC \\
\hline 30 & Lesser Adjutant & $\begin{array}{l}\text { Leptoptilos javanicus (Horsfield, } \\
\text { 1821) }\end{array}$ & 0 & 0.252 & 0 & 0 & 0 & 0.117 & VU \\
\hline 31 & Painted Stork & $\begin{array}{l}\text { Mycteria leucocephala (Pennant, } \\
1769 \text { ) }\end{array}$ & 0.002 & 0.252 & 0 & 0 & 0.117 & 0.117 & NT \\
\hline \multicolumn{10}{|c|}{ Order COLUMBIFORMES } \\
\hline \multicolumn{10}{|c|}{ Family Columbidae } \\
\hline 32 & $\begin{array}{l}\text { Grey-capped Emerald } \\
\text { Dove }\end{array}$ & $\begin{array}{l}\text { Chalcophaps indica (Linnaeus, } \\
\text { 1758) }\end{array}$ & 0.008 & 1.006 & 1.011 & 0.997 & 0.932 & 1.001 & LC \\
\hline 33 & Oriental Turtle-dove & $\begin{array}{l}\text { Streptopelia orientalis (Latham, } \\
\text { 1790) }\end{array}$ & 0.004 & 0.503 & 0.005 & 0.443 & 0.466 & 0.47 & LC \\
\hline 34 & Red Turtle-dove & $\begin{array}{l}\text { Streptopelia tranquebarica } \\
\text { (Hermann, 1804) }\end{array}$ & 0.004 & 0.503 & 0.005 & 0.554 & 0.466 & 0.53 & LC \\
\hline 35 & Rock Dove & Columba livia Gmelin, 1789 & 0.005 & 0 & 0.004 & 0 & 0.466 & 0 & LC \\
\hline 36 & Western Spotted Dove & $\begin{array}{l}\text { Spilopelia suratensis (Gmelin, } \\
\text { 1789) }\end{array}$ & 0.019 & 0.628 & 0.008 & 4.212 & 1.399 & 2.53 & LC \\
\hline \multicolumn{10}{|c|}{ Order CORACIIFORMES } \\
\hline \multicolumn{10}{|c|}{ Family Alcedinidae } \\
\hline 37 & Common Kingfisher & Alcedo atthis (Linnaeus, 1758) & 0.005 & 0.628 & 0.007 & 0.554 & 0.583 & 0.589 & LC \\
\hline 38 & Pied Kingfisher & Ceryle rudis (Linnaeus, 1758) & 0 & 0.252 & 0.001 & 0 & 0.058 & 0.117 & LC \\
\hline 39 & Stork-billed Kingfisher & $\begin{array}{l}\text { Pelargopsis capensis (Linnaeus, } \\
\text { 1766) }\end{array}$ & 0.002 & 0 & 0 & 0 & 0.117 & 0 & LC \\
\hline 40 & $\begin{array}{l}\text { White-breasted } \\
\text { Kingfisher }\end{array}$ & $\begin{array}{l}\text { Halcyon smyrnensis (Linnaeus, } \\
\text { 1758) }\end{array}$ & 0.07 & 0.88 & 0.012 & 2.1 & 0.932 & 1.532 & LC \\
\hline \multicolumn{10}{|c|}{ Family Coraciidae } \\
\hline 41 & Indian Roller & $\begin{array}{l}\text { Coracias benghalensis (Linnaeus, } \\
1758 \text { ) }\end{array}$ & 0.05 & 0.628 & 0.007 & 0.554 & 0.583 & 0.589 & LC \\
\hline \multicolumn{10}{|c|}{ Family Meropidae } \\
\hline 42 & Asian Green Bee-eater & Merops orientalis Latham, 1802 & 1.018 & 2.138 & 2.013 & 2.106 & 1.573 & 2.121 & LC \\
\hline 43 & Blue-tailed Bee-eater & $\begin{array}{l}\text { Merops philippinus Linnaeus, } \\
1766\end{array}$ & 2.038 & 3.899 & 3.048 & 3.215 & 4.254 & 3.535 & LC \\
\hline 44 & $\begin{array}{l}\text { Chestnut-headed Bee- } \\
\text { eater }\end{array}$ & $\begin{array}{l}\text { Merops leschenaulti Vieillot, } \\
1817\end{array}$ & 0.004 & 0.503 & 0.005 & 0.222 & 0.466 & 0.353 & LC \\
\hline \multicolumn{10}{|c|}{ Order CUCULIFORMES } \\
\hline \multicolumn{10}{|c|}{ Family Cuculidae } \\
\hline 45 & Banded Bay Cuckoo & $\begin{array}{l}\text { Cacomantis sonneratii (Latham, } \\
\text { 1790) }\end{array}$ & 0.002 & 0.252 & 0.003 & 0.222 & 0.233 & 0.23 & LC \\
\hline 46 & Common Hawk-cuckoo & Hierococcyx varius (Vahl, 1797) & 0.002 & 0.252 & 0.003 & 0.222 & 0.233 & 0.23 & LC \\
\hline 47 & Greater Coucal & $\begin{array}{l}\text { Centropus sinensis (Stephens, } \\
\text { 1815) }\end{array}$ & 0.002 & 0.252 & 0.003 & 0.222 & 0.233 & 0.23 & LC \\
\hline 48 & Indian Cuckoo & Cuculus micropterus Gould, 1837 & 0.003 & 0.377 & 0.004 & 0 & 0.35 & 0.176 & LC \\
\hline
\end{tabular}




\begin{tabular}{|c|c|c|c|c|c|c|c|c|c|}
\hline & \multirow[b]{2}{*}{$\begin{array}{l}\text { Order/Family/ } \\
\text { Common name }\end{array}$} & \multirow[b]{2}{*}{ Zoological name } & \multicolumn{2}{|c|}{ RA in Winter } & \multicolumn{2}{|c|}{ RA in Summer } & \multicolumn{2}{|c|}{ Total RA( \%) } & \multirow{2}{*}{$\begin{array}{c}\text { IUCN } \\
\text { category }\end{array}$} \\
\hline & & & Protected & $\begin{array}{c}\text { Non- } \\
\text { protected }\end{array}$ & Protected & $\begin{array}{c}\text { Non- } \\
\text { protected }\end{array}$ & Protected & $\begin{array}{c}\text { Non- } \\
\text { protected }\end{array}$ & \\
\hline 49 & Lesser Coucal & $\begin{array}{l}\text { Centropus bengalensis (Gmelin, } \\
\text { 1788) }\end{array}$ & 0.008 & 1.006 & 0.009 & 0.776 & 0.874 & 0.88 & LC \\
\hline 50 & Western Koel & $\begin{array}{l}\text { Eudynamys scolopaceus } \\
\text { (Linnaeus, 1758) }\end{array}$ & 0.002 & 0 & 0.003 & 0 & 0.233 & 0 & LC \\
\hline \multicolumn{10}{|c|}{ Order FALCONIFORMES } \\
\hline \multicolumn{10}{|c|}{ Family Falconidae } \\
\hline 51 & Red-headed Falcon & Falco chicquera Daudin, 1800 & 0.002 & 0 & 0.003 & 0 & 0.233 & 0 & NT \\
\hline \multicolumn{10}{|c|}{ Order GALLIFORMES } \\
\hline \multicolumn{10}{|c|}{ Family Phasianidae } \\
\hline 52 & Black Francolin & $\begin{array}{l}\text { Francolinus francolinus } \\
\text { (Linnaeus, 1766) }\end{array}$ & 0.004 & 0.252 & 0.003 & 0.221 & 0.35 & 0.23 & LC \\
\hline 53 & Common Peafowl & Pavo cristatus Linnaeus, 1758 & 3.052 & 2.767 & 4.047 & 2.328 & 4.953 & 2.53 & LC \\
\hline 54 & Common Quail & $\begin{array}{l}\text { Coturnix coturnix (Linnaeus, } \\
1758 \text { ) }\end{array}$ & 0.004 & 0 & 0.008 & 0 & 0.583 & 0 & LC \\
\hline 55 & Red Junglefowl & Gallus gallus (Linnaeus, 1758) & 0.804 & 0.503 & 0.005 & 0.443 & 0.466 & 0.471 & LC \\
\hline 56 & Common Coot & Fulica atra Linnaeus, 1758 & 0.01 & 0 & 0 & 0.554 & 0.583 & 0.294 & LC \\
\hline \multicolumn{10}{|c|}{ Order GRUIFORMES } \\
\hline \multicolumn{10}{|c|}{ Family Rallidae } \\
\hline 57 & Ruddy-breasted Crake & Zapornia fusca (Linnaeus, 1766) & 0.015 & 0 & 0.017 & 0 & 1.632 & 0 & LC \\
\hline 58 & Watercock & Gallicrex cinerea (Gmelin, 1789) & 0.01 & 1.258 & 0.004 & 0 & 0.758 & 0.58 & LC \\
\hline 59 & $\begin{array}{l}\text { White-breasted } \\
\text { Waterhen }\end{array}$ & $\begin{array}{l}\text { Amaurornis phoenicurus } \\
\text { (Pennant, 1769) }\end{array}$ & 0.003 & 0.377 & 0 & 0 & 0.175 & 0.17 & LC \\
\hline \multicolumn{10}{|c|}{ Order PASSERIFORMES } \\
\hline \multicolumn{10}{|c|}{ Family Alaudidae } \\
\hline 60 & Rufous-winged Lark & Mirafra assamica Horsfield, 1840 & 0.715 & 1.88 & 2.017 & 1.33 & 1.632 & 1.591 & LC \\
\hline 61 & Sand Lark & Alaudala raytal (Blyth, 1844) & 0.002 & 0.25 & 0 & 0.221 & 0.117 & 0.23 & LC \\
\hline \multicolumn{10}{|c|}{ Family Campephagidae } \\
\hline 62 & Scarlet Minivet & $\begin{array}{l}\text { Pericrocotus flammeus (Forster, } \\
\text { 1781) }\end{array}$ & 0.006 & 0.754 & 0.009 & 0.665 & 0.758 & 0.7 & LC \\
\hline \multicolumn{10}{|c|}{ Family Cisticolidae } \\
\hline 63 & Jungle Prinia & Prinia sylvatica Jerdon, 1840 & 0.005 & 0.628 & 0.005 & 0 & 0.524 & 0.294 & LC \\
\hline 64 & Zitting Cisticola & $\begin{array}{l}\text { Cisticola juncidis (Rafinesque, } \\
1810 \text { ) }\end{array}$ & 0.004 & 0.503 & 0.004 & 0.443 & 0.408 & 0.471 & LC \\
\hline \multicolumn{10}{|c|}{ Family Corvidae } \\
\hline 65 & Grey Treepie & $\begin{array}{l}\text { Dendrocitta formosae Swinhoe, } \\
1863\end{array}$ & 0.002 & 0 & 0.003 & 0 & 0.233 & 0 & LC \\
\hline 66 & House Crow & Corvus splendens Vieillot, 1817 & 0.915 & 1.88 & 1.012 & 2.439 & 1.399 & 2.18 & LC \\
\hline 67 & Large-billed Crow & $\begin{array}{l}\text { Corvus macrorhynchos Wagler, } \\
1827\end{array}$ & 0.004 & 0.503 & 0.008 & 1.441 & 0.583 & 1 & LC \\
\hline 68 & Red-billed Blue Magpie & $\begin{array}{l}\text { Urocissa erythroryncha } \\
\text { (Boddaert, 1783) }\end{array}$ & 0.002 & 0.25 & 0.003 & 0.221 & 0.233 & 0.235 & LC \\
\hline 69 & Rufous Treepie & $\begin{array}{l}\text { Dendrocitta vagabunda (Latham, } \\
\text { 1790) }\end{array}$ & 0.004 & 0.503 & 0.004 & 0.554 & 0.408 & 0.53 & LC \\
\hline \multicolumn{10}{|c|}{ Family Dicruridae } \\
\hline 70 & Ashy Drongo & $\begin{array}{l}\text { Dicrurus leucophaeus Vieillot, } \\
1817\end{array}$ & 0.005 & 0.628 & 0.007 & 0.55 & 0.583 & 0.58 & LC \\
\hline 71 & Black Drongo & $\begin{array}{l}\text { Dicrurus macrocercus Vieillot, } \\
1817\end{array}$ & 1.015 & 1.88 & 2.017 & 1.88 & 1.632 & 1.885 & LC \\
\hline 72 & $\begin{array}{l}\text { Greater Racquet-tailed } \\
\text { Drongo }\end{array}$ & $\begin{array}{l}\text { Dicrurus paradiseus (Linnaeus, } \\
1766 \text { ) }\end{array}$ & 0.004 & 0.503 & 0.003 & 0.44 & 0.35 & 0.47 & LC \\
\hline 73 & $\begin{array}{l}\text { Lesser Racquet-tailed } \\
\text { Drongo }\end{array}$ & $\begin{array}{l}\text { Dicrurus remifer (Temminck, } \\
\text { 1823) }\end{array}$ & 0.002 & 0.252 & 0.003 & 0.221 & 0.233 & 0.23 & LC \\
\hline
\end{tabular}




\begin{tabular}{|c|c|c|c|c|c|c|c|c|c|}
\hline & \multirow[b]{2}{*}{$\begin{array}{l}\text { Order/Family/ } \\
\text { Common name }\end{array}$} & \multirow[b]{2}{*}{ Zoological name } & \multicolumn{2}{|c|}{ RA in Winter } & \multicolumn{2}{|c|}{ RA in Summer } & \multicolumn{2}{|c|}{ Total RA( \%) } & \multirow{2}{*}{$\begin{array}{l}\text { IUCN } \\
\text { category }\end{array}$} \\
\hline & & & Protected & $\begin{array}{c}\text { Non- } \\
\text { protected }\end{array}$ & Protected & $\begin{array}{c}\text { Non- } \\
\text { protected }\end{array}$ & Protected & $\begin{array}{c}\text { Non- } \\
\text { protected }\end{array}$ & \\
\hline 74 & White-bellied Drongo & $\begin{array}{l}\text { Dicrurus caerulescens (Linnaeus, } \\
1758 \text { ) }\end{array}$ & 0 & 0 & 0 & 0.332 & 0 & 0.176 & LC \\
\hline \multicolumn{10}{|c|}{ Family Estrildidae } \\
\hline 75 & Scaly-breasted Munia & $\begin{array}{l}\text { Lonchura punctulata (Linnaeus, } \\
\text { 1758) }\end{array}$ & 0.005 & 0.628 & 0.007 & 0.554 & 0.583 & 0.589 & LC \\
\hline \multicolumn{10}{|c|}{ Family Hirundinidae } \\
\hline 76 & Barn Swallow & Hirundo rustica Linnaeus, 1758 & 1.023 & 2.642 & 2.028 & 2.771 & 2.506 & 2.71 & LC \\
\hline 77 & Wire-tailed Swallow & Hirundo smithii Leach, 1818 & 2.026 & 3.144 & 3.036 & 2.771 & 3.03 & 2.946 & LC \\
\hline \multicolumn{10}{|c|}{ Family Laniidae } \\
\hline 78 & Grey-backed Shrike & $\begin{array}{l}\text { Lanius tephronotus (Vigors, } \\
\text { 1831) }\end{array}$ & 0 & 0 & 0.33 & 0.001 & 0.176 & 0.058 & LC \\
\hline \multicolumn{10}{|c|}{ Family Leiotrichidae } \\
\hline 79 & Common Babbler & Argya caudata (Dumont, 1823) & 0.004 & 0.503 & 0.005 & 0.665 & 0.466 & 0.589 & LC \\
\hline 80 & Jungle Babbler & Turdoides striata (Dumont, 1823) & 1.014 & 1.761 & 2.016 & 1.33 & 1.515 & 1.53 & LC \\
\hline 81 & Large Grey Babbler & Argya malcolmi (Sykes, 1832) & 0 & 0 & 0.005 & 0 & 0.233 & 0 & LC \\
\hline \multicolumn{10}{|c|}{ Family Monarchidae } \\
\hline 82 & Black-naped Monarch & $\begin{array}{l}\text { Hypothymis azurea (Boddaert, } \\
1783 \text { ) }\end{array}$ & 0.905 & 0.628 & 0.807 & 0.554 & 0.583 & 0.589 & LC \\
\hline 83 & White Wagtail & Motacilla alba Linnaeus, 1758 & 0 & 0 & 0 & 1.108 & 0 & 0.589 & LC \\
\hline 84 & White-browed Wagtail & $\begin{array}{l}\text { Motacilla maderaspatensis } \\
\text { Gmelin, } 1789\end{array}$ & 0.004 & 0.503 & 0.005 & 0.554 & 0.466 & 0.53 & LC \\
\hline \multicolumn{10}{|c|}{ Family Muscicapidae } \\
\hline 85 & Black Redstart & $\begin{array}{l}\text { Phoenicurus ochruros (Gmelin, } \\
\text { 1774) }\end{array}$ & 0 & 0.629 & 0 & 0 & 0 & 0.294 & LC \\
\hline 86 & Common Stonechat & $\begin{array}{l}\text { Saxicola torquatus (Linnaeus, } \\
1766 \text { ) }\end{array}$ & 1.017 & 1.761 & 1.015 & 1.108 & 1.573 & 1.41 & LC \\
\hline 87 & Grey Bushchat & Saxicola ferreus Gray, 1846 & 0.002 & 0.251 & 0.003 & 0.221 & 0.233 & 0.23 & LC \\
\hline 88 & Indian Robin & $\begin{array}{l}\text { Saxicoloides fulicatus (Linnaeus, } \\
\text { 1766) }\end{array}$ & 0.002 & 0.251 & 0.003 & 0.221 & 0.233 & 0.23 & LC \\
\hline 89 & Oriental Magpie-robin & $\begin{array}{l}\text { Copsychus saularis (Linnaeus, } \\
1758 \text { ) }\end{array}$ & 1.017 & 1.257 & 0.915 & 1.219 & 1.573 & 1.237 & LC \\
\hline 90 & Pied Bushchat & Saxicola caprata (Linnaeus, 1766) & 0 & 0 & 0 & 0.332 & 0 & 0.176 & LC \\
\hline 91 & $\begin{array}{l}\text { White-capped Water- } \\
\text { redstart }\end{array}$ & $\begin{array}{l}\text { Phoenicurus leucocephalus } \\
\text { (Vigors, 1831) }\end{array}$ & 0.005 & 0.628 & 0.001 & 0.554 & 0.35 & 0.589 & LC \\
\hline 92 & White-tailed Stonechat & Saxicola leucurus (Blyth, 1847) & 0.004 & 0.503 & 0 & 0.443 & 0.233 & 0.471 & LC \\
\hline \multicolumn{10}{|c|}{ Family Oriolidae } \\
\hline 93 & Black-hooded Oriole & $\begin{array}{l}\text { Oriolus xanthornus (Linnaeus, } \\
1758 \text { ) }\end{array}$ & 0.004 & 0.503 & 0.004 & 1.33 & 0.408 & 0.942 & LC \\
\hline \multicolumn{10}{|c|}{ Family Passeridae } \\
\hline 94 & $\begin{array}{l}\text { Chestnut-shouldered } \\
\text { Bush-sparrow }\end{array}$ & $\begin{array}{l}\text { Gymnoris xanthocollis (Burton, } \\
\text { 1838) }\end{array}$ & 1.015 & 1.257 & 1.615 & 1.662 & 1.515 & 1.473 & LC \\
\hline 95 & House Sparrow & $\begin{array}{l}\text { Passer domesticus (Linnaeus, } \\
\text { 1758) }\end{array}$ & 1.026 & 3.144 & 2.028 & 5.21 & 2.681 & 4.242 & LC \\
\hline \multicolumn{10}{|c|}{ Family Ploceidae } \\
\hline 96 & Baya Weaver & $\begin{array}{l}\text { Ploceus philippinus (Linnaeus, } \\
1766 \text { ) }\end{array}$ & 0.01 & 1.257 & 0.016 & 0.776 & 1.282 & 1 & LC \\
\hline \multicolumn{10}{|c|}{ Family Pycnonotidae } \\
\hline 97 & Black Bulbul & $\begin{array}{l}\text { Hypsipetes leucocephalus } \\
\text { (Gmelin, 1789) }\end{array}$ & 1.01 & 1.257 & 2.015 & 1.108 & 1.224 & 1.17 & LC \\
\hline 98 & Red-vented Bulbul & $\begin{array}{l}\text { Pycnonotus cafer (Linnaeus, } \\
1766)\end{array}$ & 0.006 & 0 & 0.008 & 0.665 & 0.699 & 0.35 & LC \\
\hline 99 & Red-whiskered Bulbul & $\begin{array}{l}\text { Pycnonotus jocosus (Linnaeus, } \\
1758 \text { ) }\end{array}$ & 1.017 & 2.012 & 1.019 & 1.995 & 1.748 & 2 & LC \\
\hline
\end{tabular}




\begin{tabular}{|c|c|c|c|c|c|c|c|c|c|}
\hline & \multirow[b]{2}{*}{$\begin{array}{l}\text { Order/Family/ } \\
\text { Common name }\end{array}$} & \multirow[b]{2}{*}{ Zoological name } & \multicolumn{2}{|c|}{ RA in Winter } & \multicolumn{2}{|c|}{ RA in Summer } & \multicolumn{2}{|c|}{ Total RA( \%) } & \multirow{2}{*}{$\begin{array}{c}\text { IUCN } \\
\text { category }\end{array}$} \\
\hline & & & Protected & $\begin{array}{c}\text { Non- } \\
\text { protected }\end{array}$ & Protected & $\begin{array}{c}\text { Non- } \\
\text { protected }\end{array}$ & Protected & $\begin{array}{c}\text { Non- } \\
\text { protected }\end{array}$ & \\
\hline \multicolumn{10}{|c|}{ Family Scotocercidae } \\
\hline 100 & $\begin{array}{l}\text { Pale-footed Bush- } \\
\text { warbler }\end{array}$ & $\begin{array}{l}\text { Hemitesia pallidipes (Blanford, } \\
\text { 1872) }\end{array}$ & 0.002 & 0.251 & 0.003 & 0.221 & 0.233 & 0.235 & LC \\
\hline \multicolumn{10}{|c|}{ Family Sturnidae } \\
\hline 101 & Asian-pied Starling & $\begin{array}{l}\text { Gracupica contra (Linnaeus, } \\
1758 \text { ) }\end{array}$ & 0 & 0 & 0 & 0.886 & 0 & 0.471 & LC \\
\hline 102 & Common Myna & $\begin{array}{l}\text { Acridotheres tristis (Linnaeus, } \\
1766 \text { ) }\end{array}$ & 1.015 & 1.886 & 2.019 & 1.99 & 1.69 & 1.944 & LC \\
\hline 103 & Jungle Myna & $\begin{array}{l}\text { Acridotheres fuscus (Wagler, } \\
\text { 1827) }\end{array}$ & 1.012 & 1.509 & 1.015 & 2.1 & 1.34 & 1.826 & LC \\
\hline \multicolumn{10}{|c|}{ Family: Zosteropidae } \\
\hline 104 & Indian White-eye & \begin{tabular}{|l|} 
Zosterops palpebrosus \\
(Temminck, 1824)
\end{tabular} & 0.002 & 0.251 & 0.003 & 0.221 & 0.233 & 0.235 & LC \\
\hline \multicolumn{10}{|c|}{ Order PELECANIFORMES } \\
\hline \multicolumn{10}{|c|}{ Family Ardeidae } \\
\hline 105 & Cattle Egret & Bubulcus ibis (Linnaeus, 1758) & 0.805 & 0.628 & 0.005 & 7.649 & 0.524 & 4.36 & LC \\
\hline 106 & Great White Egret & Ardea alba Linnaeus, 1758 & 0.006 & 0 & 0.007 & 0 & 0.641 & 0 & LC \\
\hline 107 & Grey Heron & Ardea cinerea Linnaeus, 1758 & 0.004 & 0.503 & 0.005 & 0.443 & 0.466 & 0.471 & LC \\
\hline 108 & Indian Pond Heron & Ardeola grayii (Sykes, 1832) & 0 & 0 & 0.04 & 0.332 & 1.748 & 0.176 & LC \\
\hline 109 & Intermediate Egret & Ardea intermedia Wagler, 1829 & 0.003 & 0.628 & 0.004 & 0.554 & 0.35 & 0.589 & LC \\
\hline 110 & Little Egret & Egretta garzetta (Linnaeus, 1766) & 0.004 & 0.503 & 0.005 & 0.997 & 0.466 & 0.766 & LC \\
\hline 111 & Purple Heron & Ardea purpurea Linnaeus, 1766 & 0.004 & 0 & 0.005 & 0.443 & 0.466 & 0.235 & LC \\
\hline \multicolumn{10}{|c|}{ Family Threskiornithidae } \\
\hline 112 & Red-naped Ibis & \begin{tabular}{|l} 
Pseudibis papillosa (Temminck, \\
1824)
\end{tabular} & 0.004 & 0.503 & 0.005 & 0.11 & 0.466 & 0.294 & LC \\
\hline \multicolumn{10}{|c|}{ Order PICIFORMES } \\
\hline \multicolumn{10}{|c|}{ Family Megalaimidae } \\
\hline 113 & Brown-headed Barbet & $\begin{array}{l}\text { Psilopogon zeylanicus (Gmelin, } \\
\text { 1788) }\end{array}$ & 0.002 & 0.251 & 0.003 & 0.221 & 0.233 & 0.235 & LC \\
\hline 114 & Coppersmith Barbet & $\begin{array}{l}\text { Psilopogon haemacephalus } \\
\text { (Müller, 1776) }\end{array}$ & 0.005 & 0.628 & 0.005 & 0.55 & 0.524 & 0.589 & LC \\
\hline \multicolumn{10}{|c|}{ Family Picidae } \\
\hline 115 & $\begin{array}{l}\text { Brown-capped Pygmy } \\
\text { Woodpecker }\end{array}$ & Picoides nanus (Vigors, 1832) & 0 & 1.509 & 0 & 1.77 & 0 & 1.649 & LC \\
\hline 116 & $\begin{array}{l}\text { Great Slaty } \\
\text { Woodpecker }\end{array}$ & $\begin{array}{l}\text { Mulleripicus pulverulentus } \\
\text { (Temminck, 1826) }\end{array}$ & 0.002 & 0.251 & 0.003 & 0 & 0.233 & 0.117 & vu \\
\hline 117 & $\begin{array}{l}\text { Indian Pygmy } \\
\text { Woodpecker }\end{array}$ & Picoides nanus (Vigors, 1832) & 1.012 & 0.503 & 1.012 & 0 & 1.224 & 0.235 & LC \\
\hline 118 & Lesser Yellownape & Picus chlorolophus Vieillot, 1818 & 0.004 & 0 & 0.005 & 0 & 0.466 & 0 & LC \\
\hline 119 & Greater Flameback & $\begin{array}{l}\text { Chrysocolaptes guttacristatus } \\
\text { (Tickell, 1833) }\end{array}$ & 0.808 & 0.503 & 0.78 & 0.44 & 0.816 & 0.471 & LC \\
\hline 120 & $\begin{array}{l}\text { Yellow-crowned } \\
\text { Woodpecker }\end{array}$ & $\begin{array}{l}\text { Leiopicus mahrattensis (Latham, } \\
\text { 1801) }\end{array}$ & 0.005 & 0.628 & 0.004 & 0.554 & 0.466 & 0.589 & LC \\
\hline \multicolumn{10}{|c|}{ Order PSITTACIFORMES } \\
\hline \multicolumn{10}{|c|}{ Family Psittacidae } \\
\hline 121 & Plum-headed Parakeet & \begin{tabular}{|l} 
Psittacula cyanocephala \\
(Linnaeus, 1766)
\end{tabular} & 2.021 & 1.257 & 2.025 & 0.997 & 2.273 & 1.119 & LC \\
\hline 122 & Alexandrine Parakeet & $\begin{array}{l}\text { Psittacula eupatria (Linnaeus, } \\
1766 \text { ) }\end{array}$ & 2.019 & 1.257 & 0 & 0.886 & 1.049 & 1.06 & NT \\
\hline 123 & Rose-ringed Parakeet & Psittacula krameri (Scopoli, 1769) & 1.01 & 1.509 & 2.016 & 1.33 & 1.282 & 1.414 & LC \\
\hline 124 & Slaty-headed Parakeet & $\begin{array}{l}\text { Psittacula himalayana (Lesson, } \\
\text { 1832) }\end{array}$ & 3.031 & 4.02 & 2.02 & 2.439 & 2.622 & 3.18 & LC \\
\hline
\end{tabular}




\begin{tabular}{|c|c|c|c|c|c|c|c|c|c|}
\hline & \multirow[b]{2}{*}{$\begin{array}{l}\text { Order/Family/ } \\
\text { Common name }\end{array}$} & \multirow[b]{2}{*}{ Zoological name } & \multicolumn{2}{|c|}{ RA in Winter } & \multicolumn{2}{|c|}{ RA in Summer } & \multicolumn{2}{|c|}{ Total RA( \%) } & \multirow{2}{*}{$\begin{array}{c}\text { IUCN } \\
\text { category }\end{array}$} \\
\hline & & & Protected & $\begin{array}{c}\text { Non- } \\
\text { protected }\end{array}$ & Protected & $\begin{array}{c}\text { Non- } \\
\text { protected }\end{array}$ & Protected & $\begin{array}{c}\text { Non- } \\
\text { protected }\end{array}$ & \\
\hline \multicolumn{10}{|c|}{ Order STRIGIFORMES } \\
\hline \multicolumn{10}{|c|}{ Family Strigidae } \\
\hline 125 & Jungle Owlet & $\begin{array}{l}\text { Glaucidium radiatum (Tickell, } \\
\text { 1833) }\end{array}$ & 0.001 & 0 & 0.001 & 0 & 0.117 & 0 & LC \\
\hline 126 & Spotted Owlet & Athene brama (Temminck, 1821) & 0.001 & 0 & 0.001 & 0 & 0.117 & 0 & LC \\
\hline \multicolumn{10}{|c|}{ Order SULIFORMES } \\
\hline \multicolumn{10}{|c|}{ Family Anhingidae } \\
\hline 127 & Oriental Darter & $\begin{array}{l}\text { Anhinga melanogaster Pennant, } \\
1769\end{array}$ & 0.002 & 0.125 & 0 & 0 & 0.117 & 0.058 & NT \\
\hline \multicolumn{10}{|c|}{ Family Phalacrocoracidae } \\
\hline 128 & Great Cormorant & $\begin{array}{l}\text { Phalacrocorax carbo (Linnaeus, } \\
\text { 1758) }\end{array}$ & 0.01 & 0.503 & 0 & 0.443 & 0.583 & 0.47 & LC \\
\hline 129 & Little Cormorant & Microcarbo niger (Vieillot, 1817) & 1.017 & 1.006 & 1.019 & 0.997 & 1.748 & 1 & LC \\
\hline
\end{tabular}

Authors details: JAGAN NATH ADHIKARI has a keen interest in the ecology, behavior and conservation of birds, large mammals and herpetofauna. Jagan has authored or co-authored more than ten peer-reviewed papers on birds, mammals, and human-wildlife interactions and three textbooks of zoology for undergraduate level. JANAK RAJ KHATIWADA, PhD is a wild life biologist with extensive field experience in Himalayan region. He has authored or co-authored more than 15 peer-reviewed papers on taxonomy, thermal ecology, composition, distribution, and conservation status of the herpetofauna of different parts of Nepal, India and China. To date, he has described four new species of amphibians for science from Nepal and India. DIPENDRA ADHIKARI is a wildlife biologist with field experience in lowland to highland of Nepal. His research interests include diversity and distribution patterns of small mammals, birds and photographic capture recapture of megafauna such as tigers, elephants. SUMAN SAPKOTA's research interests include ecology of frogs, bioacoustics, endemic and threatened frogs and effect of climate change on frogs. He has been involved in different researches related to herpetofauna and presented his work in different national and international conferences. He is currently working as Conservation Officer in Friends of Nature (FON), Nepal. BISHNU PRASAD BHATTARAI, PhD is a conservation biologist His research interests include the conservation of large carnivores, their habitats, and prey, biogeography of Himalayan flora and fauna (e.g., birds, mammals, herpetofauna, and orchids), forest and wildlife habitat management. DEEPAK RIJAL, PhD is nationally reputed scholar of biodiversity. Over 30 years Deepak with specialist expertise in ecological adaptation has been actively involved in research and conservation of agriculture, forest, and freshwater resources. He has been a prolific writer and has been the lead and co-author for knowledge products published nationally and internationally. Deepak as a Board Chair of the nationally reputed research and development nongovernment organization consistently provides strategic direction that contributes to knowledge and benefit to various end-users in Nepal and abroad. LILA NATH SHARMA, PhD is a researcher at ForestAction Nepal. He is an ecologist and undertakes action research related to biodiversity conservation, forest restoration, and invasive species management.

Author's contributions: JNA designed the study, carried out the fieldwork, analysed the data and prepare draft, JRK designed the study, analysed the data and revised the draft, DA carried out the fieldwork and revised the final draft, SS carried out the fieldwork and revised the final draft, BPB prepared map and revised the final draft, DR revised the final draft, LNS designed the study, helped in fieldwork, analysed and helped for the preparation of manuscript and revised the draft. 
Dr. John Noyes, Natural History Museum, London, UK

Dr. Albert G. Orr, Griffith University, Nathan, Australia

Dr. Sameer Padhye, Katholieke Universiteit Leuven, Belgium

Dr. Nancy van der Poorten, Toronto, Canada

Dr. Kareen Schnabel, NIWA, Wellington, New Zealand

Dr. R.M. Sharma, (Retd.) Scientist, Zoological Survey of India, Pune, India

Dr. Manju Siliwal, WILD, Coimbatore, Tamil Nadu, India

Dr. G.P. Sinha, Botanical Survey of India, Allahabad, India

Dr. K.A. Subramanian, Zoological Survey of India, New Alipore, Kolkata, India

Dr. P.M. Sureshan, Zoological Survey of India, Kozhikode, Kerala, India

Dr. R. Varatharajan, Manipur University, Imphal, Manipur, India

Dr. Eduard Vives, Museu de Ciències Naturals de Barcelona, Terrassa, Spain

Dr. James Young, Hong Kong Lepidopterists' Society, Hong Kong

Dr. R. Sundararaj, Institute of Wood Science \& Technology, Bengaluru, India

Dr. M. Nithyanandan, Environmental Department, La Ala Al Kuwait Real Estate. Co. K.S.C.,

Kuwait

Dr. Himender Bharti, Punjabi University, Punjab, India

Mr. Purnendu Roy, London, UK

Dr. Saito Motoki, The Butterfly Society of Japan, Tokyo, Japan

Dr. Sanjay Sondhi, TITLI TRUST, Kalpavriksh, Dehradun, India

Dr. Nguyen Thi Phuong Lien, Vietnam Academy of Science and Technology, Hanoi, Vietnam

Dr. Nitin Kulkarni, Tropical Research Institute, Jabalpur, India

Dr. Robin Wen Jiang Ngiam, National Parks Board, Singapore

Dr. Lional Monod, Natural History Museum of Geneva, Genève, Switzerland.

Dr. Asheesh Shivam, Nehru Gram Bharti University, Allahabad, India

Dr. Rosana Moreira da Rocha, Universidade Federal do Paraná, Curitiba, Brasi

Dr. Kurt R. Arnold, North Dakota State University, Saxony, Germany

Dr. James M. Carpenter, American Museum of Natural History, New York, USA

Dr. David M. Claborn, Missouri State University, Springfield, USA

Dr. Kareen Schnabel, Marine Biologist, Wellington, New Zealand

Dr. Amazonas Chagas Júnior, Universidade Federal de Mato Grosso, Cuiabá, Brasil

Mr. Monsoon Jyoti Gogoi, Assam University, Silchar, Assam, India

Dr. Heo Chong Chin, Universiti Teknologi MARA (UiTM), Selangor, Malaysia

Dr. R.J. Shiel, University of Adelaide, SA 5005, Australia

Dr. Siddharth Kulkarni, The George Washington University, Washington, USA

Dr. Priyadarsanan Dharma Rajan, ATREE, Bengaluru, India

Dr. Phil Alderslade, CSIRO Marine And Atmospheric Research, Hobart, Australia

Dr. John E.N. Veron, Coral Reef Research, Townsville, Australia

Dr. Daniel Whitmore, State Museum of Natural History Stuttgart, Rosenstein, Germany.

Dr. Yu-Feng Hsu, National Taiwan Normal University, Taipei City, Taiwan

Dr. Keith V. Wolfe, Antioch, California, USA

Dr. Siddharth Kulkarni, The Hormiga Lab, The George Washington University, Washington,

D.C., USA

Dr. Tomas Ditrich, Faculty of Education, University of South Bohemia in Ceske

Budejovice, Czech Republic

Dr. Mihaly Foldvari, Natural History Museum, University of Oslo, Norway

Dr. V.P. Uniyal, Wildlife Institute of India, Dehradun, Uttarakhand 248001, India

Dr. John T.D. Caleb, Zoological Survey of India, Kolkata, West Bengal, India

Dr. Priyadarsanan Dharma Rajan, Ashoka Trust for Research in Ecology and the Environment

(ATREE), Royal Enclave, Bangalore, Karnataka, India

\section{Fishes}

Dr. Neelesh Dahanukar, IISER, Pune, Maharashtra, India

Dr. Topiltzin Contreras MacBeath, Universidad Autónoma del estado de Morelos, México

Dr. Heok Hee Ng, National University of Singapore, Science Drive, Singapore

Dr. Rajeev Raghavan, St. Albert's College, Kochi, Kerala, India

Dr. Robert D. Sluka, Chiltern Gateway Project, A Rocha UK, Southall, Middlesex, UK

Dr. E. Vivekanandan, Central Marine Fisheries Research Institute, Chennai, India

Dr. Davor Zanella, University of Zagreb, Zagreb, Croatia

Dr. A. Biju Kumar, University of Kerala, Thiruvananthapuram, Kerala, India

Dr. Akhilesh K.V., ICAR-Central Marine Fisheries Research Institute, Mumbai Research

Centre, Mumbai, Maharashtra, India

Dr. J.A. Johnson, Wildlife Institute of India, Dehradun, Uttarakhand, India

Amphibians

Dr. Sushil K. Dutta, Indian Institute of Science, Bengaluru, Karnataka, India

Dr. Annemarie Ohler, Muséum national d'Histoire naturelle, Paris, France

\section{Reptiles}

Dr. Gernot Vogel, Heidelberg, Germany

Dr. Raju Vyas, Vadodara, Gujarat, India

Dr. Pritpal S. Soorae, Environment Agency, Abu Dubai, UAE.

Prof. Dr. Wayne J. Fuller, Near East University, Mersin, Turkey

Prof. Chandrashekher U. Rivonker, Goa University, Taleigao Plateau, Goa. India

Dr. S.R. Ganesh, Chennai Snake Park, Chennai, Tamil Nadu, India

Dr. Himansu Sekhar Das, Terrestrial \& Marine Biodiversity, Abu Dhabi, UAE
Birds

Dr. Hem Sagar Baral, Charles Sturt University, NSW Australia

Dr. Chris Bowden, Royal Society for the Protection of Birds, Sandy, UK

Dr. Priya Davidar, Pondicherry University, Kalapet, Puducherry, India

Dr. J.W. Duckworth, IUCN SSC, Bath, UK

Dr. Rajah Jayapal, SACON, Coimbatore, Tamil Nadu, India

Dr. Rajiv S. Kalsi, M.L.N. College, Yamuna Nagar, Haryana, India

Dr. V. Santharam, Rishi Valley Education Centre, Chittoor Dt., Andhra Pradesh, India

Dr. S. Balachandran, Bombay Natural History Society, Mumbai, India

Mr. J. Praveen, Bengaluru, India

Dr. C. Srinivasulu, Osmania University, Hyderabad, India

Dr. K.S. Gopi Sundar, International Crane Foundation, Baraboo, USA

Dr. Gombobaatar Sundev, Professor of Ornithology, Ulaanbaatar, Mongolia

Prof. Reuven Yosef, International Birding \& Research Centre, Eilat, Israel

Dr. Taej Mundkur, Wetlands International, Wageningen, The Netherlands

Dr. Carol Inskipp, Bishop Auckland Co., Durham, UK

Dr. Tim Inskipp, Bishop Auckland Co, Durham, UK

Dr. V. Gokula, National College, Tiruchirappalli, Tamil Nadu, India

Dr. Arkady Lelej, Russian Academy of Sciences, Vladivostok, Russia

Dr. Simon Dowell, Science Director, Chester Zoo, UK

Dr. Mário Gabriel Santiago dos Santos, Universidade de Trás-os-Montes e Alto Douro,

Quinta de Prados, Vila Real, Portugal

Dr. Grant Connette, Smithsonian Institution, Royal, VA, USA

Dr. M. Zafar-ul Islam, Prince Saud Al Faisal Wildlife Research Center, Taif, Saudi Arabia

Mammals

Dr. Giovanni Amori, CNR - Institute of Ecosystem Studies, Rome, Italy

Dr. Anwaruddin Chowdhury, Guwahati, India

Dr. David Mallon, Zoological Society of London, UK

Dr. Shomita Mukherjee, SACON, Coimbatore, Tamil Nadu, India

Dr. Angie Appel, Wild Cat Network, Germany

Dr. P.O. Nameer, Kerala Agricultural University, Thrissur, Kerala, India

Dr. Ian Redmond, UNEP Convention on Migratory Species, Lansdown, UK

Dr. Heidi S. Riddle, Riddle's Elephant and Wildlife Sanctuary, Arkansas, USA

Dr. Karin Schwartz, George Mason University, Fairfax, Virginia.

Dr. Lala A.K. Singh, Bhubaneswar, Orissa, India

Dr. Mewa Singh, Mysore University, Mysore, India

Dr. Paul Racey, University of Exeter, Devon, UK

Dr. Honnavalli N. Kumara, SACON, Anaikatty P.O., Coimbatore, Tamil Nadu, India

Dr. Nishith Dharaiya, HNG University, Patan, Gujarat, India

Dr. Spartaco Gippoliti, Socio Onorario Società Italiana per la Storia della Fauna "Giuseppe

Altobello", Rome, Italy

Dr. Justus Joshua, Green Future Foundation, Tiruchirapalli, Tamil Nadu, India

Dr. H. Raghuram, The American College, Madurai, Tamil Nadu, India

Dr. Paul Bates, Harison Institute, Kent, UK

Dr. Jim Sanderson, Small Wild Cat Conservation Foundation, Hartford, USA

Dr. Dan Challender, University of Kent, Canterbury, UK

Dr. David Mallon, Manchester Metropolitan University, Derbyshire, UK

Dr. Brian L. Cypher, California State University-Stanislaus, Bakersfield, CA

Dr. S.S. Talmale, Zoological Survey of India, Pune, Maharashtra, India

Prof. Karan Bahadur Shah, Budhanilakantha Municipality, Kathmandu, Nepal

Dr. Susan Cheyne, Borneo Nature Foundation International, Palangkaraja, Indonesia

Dr. Hemanta Kafley, Wildlife Sciences, Tarleton State University, Texas, USA

\section{Other Disciplines}

Dr. Aniruddha Belsare, Columbia MO 65203, USA (Veterinary)

Dr. Mandar S. Paingankar, University of Pune, Pune, Maharashtra, India (Molecular)

Dr. Jack Tordoff, Critical Ecosystem Partnership Fund, Arlington, USA (Communities)

Dr. Ulrike Streicher, University of Oregon, Eugene, USA (Veterinary)

Dr. Hari Balasubramanian, EcoAdvisors, Nova Scotia, Canada (Communities)

Dr. Rayanna Hellem Santos Bezerra, Universidade Federal de Sergipe, São Cristóvão, Brazil

Dr. Jamie R. Wood, Landcare Research, Canterbury, New Zealand

Dr. Wendy Collinson-Jonker, Endangered Wildlife Trust, Gauteng, South Africa

Dr. Rajeshkumar G. Jani, Anand Agricultural University, Anand, Gujarat, India

Dr. O.N. Tiwari, Senior Scientist, ICAR-Indian Agricultural Research Institute (IARI), New

Delhi, India

Dr. L.D. Singla, Guru Angad Dev Veterinary and Animal Sciences University, Ludhiana, India

Dr. Rupika S. Rajakaruna, University of Peradeniya, Peradeniya, Sri Lanka

Dr. Bahar Baviskar, Wild-CER, Nagpur, Maharashtra 440013, India

Reviewers 2018-2020

Due to pausity of space, the list of reviewers for $2018-2020$ is available online.

The opinions expressed by the authors do not reflect the views of the Journal of Threatened Taxa, Wildlife Information Liaison Development Society, Zoo Outreach Organization, or any of the partners. The journal, the publisher, the host, and the partners are not responsible for the accuracy of the political boundaries shown in the maps by the authors.

Journal of Threatened Taxa is indexed/abstracted in Bibliography of Systematic Mycology, Biological Abstracts, BIOSIS Previews, CAB Abstracts, EBSCO, Google Scholar, Index Copernicus, Index Fungorum, JournalSeek, National Academy of Agricultural Sciences, NewJour, OCLC WorldCat, SCOPUS, Stanford University Libraries, Virtual Library of Biology, Zoological Records.

NAAS rating (India) 5.64
Print copies of the Journal are available at cost. Write to:

The Managing Editor, JoTT,

c/o Wildlife Information Liaison Development Society,

No. 12, Thiruvannamalai Nagar, Saravanampatti - Kalapatti Road,

Saravanampatti, Coimbatore, Tamil Nadu 641035, India

ravi@threatenedtaxa.org 


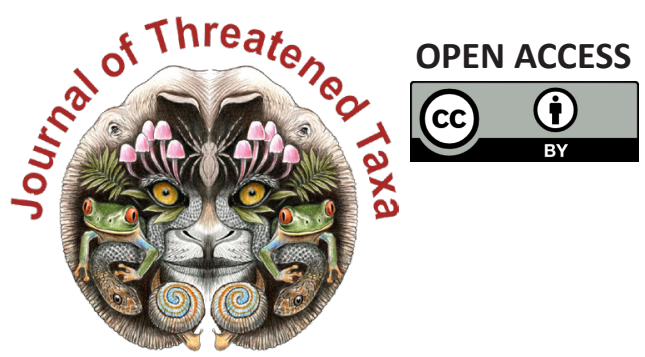

www.threatenedtaxa.org

The Journal of Threatened Taxa (JoTT) is dedicated to building evidence for conservation globally by publishing peer-reviewed articles online every month at a reasonably rapid rate at www.threatenedtaxa.org. All articles published in JoTT are registered under Creative Commons Attribution 4.0 International License unless otherwise mentioned. JoTT allows allows unrestricted use, reproduction, and distribution of articles in any medium by providing adequate credit to the author(s) and the source of publication.

\section{ISSN $0974-7907$ (Online) | ISSN $0974-7893$ (Print)}

\section{January 2022 | Vol. 14 | No. 1 | Pages: 20311-20538 \\ Date of Publication: 26 January 2022 (Online \& Print) DOI: 10.11609/jott.2022.14.1.20311-20538}

Articles

Estimating the completeness of orchid checklists and atlases: a case study from southern Italy

- Antonio Croce, Pp. 20311-20322

A floristic survey across three coniferous forests of Kashmir Himalaya, India - a checklist

- Ashaq Ahmad Dar, Akhtar Hussain Malik \& Narayanaswamy Parthasarathy, Pp. 20323-20345

Associations of butterflies across different forest types in Uttarakhand, western Himalaya, India: implications for conservation planning

- Arun Pratap Singh, Pp. 20346-20370

Comparison of bird diversity in protected and non-protected wetlands of western lowland of Nepal

- Jagan Nath Adhikari, Janak Raj Khatiwada, Dipendra Adhikari, Suman Sapkota, Bishnu Prasad Bhattarai, Deepak Rijal \& Lila Nath Sharma, Pp. 20371-20386

Local hunting practices and perceptions regarding the distribution and ecological role of the Large Flying Fox (Chiroptera: Pteropodidae: Pteropus vampyrus) in western Sarawak, Malaysian Borneo

- Jayasilan Mohd-Azlan, Joon Yee Yong, Nabila Norshuhadah Mohd Hazzrol, Philovenny Pengiran, Arianti Atong \& Sheema Abdul Aziz, Pp. 20387-20399

\section{Communications}

Macrolichens of Mathikettan Shola National Park, Western Ghats: a preliminary investigation with some new records

- Aswathi Anilkumar, Stephen Sequeira, Arun Christy \& S.M. Arsha, Pp. 20400-20405

New distribution record of globally threatened Ocean Turf Grass Halophila beccarii Ascherson, 1871 from the North Andaman Islands highlights the importance of seagrass exploratory surveys

- Swapnali Gole, Prasad Gaidhani, Srabani Bose, Anant Pande, Jeyaraj Antony Johnson \& Kuppusamy Sivakumar, Pp. 20406-20412

An inventory of new orchid (Orchidaceae) records from Kozhikode, Kerala, India - M. Sulaiman, C. Murugan \& M.U. Sharief, Pp. 20413-20425

Abundance and spatial distribution analyses of Stemonoporus moonii Thwaites (Dipterocarpaceae) - a critically endangered species endemic to Sri Lanka - K.A.M.R.P. Atapattu, H.D.D.C.K. Perera, H.S. Kathriarachchi \& A.R. Gunawardena, Pp. 20426-20432

Plant diversity of Point Calimere Wildlife Sanctuary and fodder species grazed by the Blackbuck Antilope cervicapra L.

- Ashutosh Kumar Upadhyay, A. Andrew Emmanuel, Ansa Sarah Varghese \&

D. Narasimhan, Pp. 20433-20443

Raptors observed (1983-2016) in National Chambal Gharial Sanctuary: semi-arid biogeographic region suggestions for parametric studies on ecological continuity in Khathiar-Gir Ecoregion, India

- L.A.K. Singh, R.K. Sharma \& Udayan Rao Pawar, Pp. 20444-20460

Nesting success of Sharpe's Longclaw (Macronyx sharpei Jackson, 1904) around the grasslands of lake Ol'bolossat Nyandarua, Kenya

- Hamisi Ann Risper, Charles M. Warui \& Peter Njoroge, Pp. 20461-20468

Population, distribution and diet composition of Smooth-coated Otter Lutrogale perspicillata Geoffroy, 1826 in Hosur and Dharmapuri Forest Divisions, India - Nagarajan Baskaran, Raman Sivaraj Sundarraj \& Raveendranathanpillai Sanil, Pp. 20469-20477

Utilization of home garden crops by primates and current status of human-primate interface at Galigamuwa Divisional Secretariat Division in Kegalle District, Sri Lanka

- Charmalie Anuradhie Dona Nahallage, Dahanakge Ayesha Madushani Dasanayake, Dilan Thisaru Hewamanna \& Dissanayakalage Tharaka Harshani Ananda, Pp. 2047820487
Revival of Eastern Swamp Deer Rucervus duvaucelii ranjitsinhi (Groves, 1982) in Manas National Park of Assam, India

- Nazrul Islam, Aftab Ahmed, Rathin Barman, Sanatan Deka, Bhaskar Choudhury, Prasanta Kumar Saikia \& Jyotishman Deka, Pp. 20488-20493

Trypanosoma evansi infection in a captive Indian Wolf Canis lupus pallipes - molecular diagnosis and therapy

- Manojita Dash, Sarat Kumar Sahu, Santosh Kumar Gupta, Niranjana Sahoo \& Debarat Mohapatra, Pp. 20494-20499

View Point

COVID-19 and civil unrest undoing steady gains in karst conservation and herpetological research in Myanmar, and an impediment to progress - Evan S.H. Quah, Lee L. Grismer, Perry L. Wood, Jr., Aung Lin \& Myint Kyaw Thura, Pp. 20500-20502

\section{Short Communications}

Morphological characterization and mt DNA barcode of a tiger moth species, Asota ficus (Fabricius, 1775) (Lepidoptera: Noctuoidea: Erebidae: Aganainae) from India - Aparna Sureshchandra Kalawate, K.P. Dinesh \& A. Shabnam, Pp. 20503-20510

Distribution of Smooth-coated Otters Lutrogale perspicillata (Mammalia: Carnivora: Mustelidae): in Ratnagiri, Maharashtra, India

- Swanand Patil \& Kranti Yardi, Pp. 20511-20516

Wildlife at the crossroads: wild animal road kills due to vehicular collision on a mountainous highway in northwestern Himalayan region

- Muzaffar A. Kichloo, Asha Sohil \& Neeraj Sharma, Pp. 20517-20522

Notes

Robiquetia gracilis (Lindl.) Garay-a new record to the flora of Anamalai Hills, Tami Nadu, India

- B. Subbaiyan, V. Ganesan, P.R. Nimal Kumar \& S. Thangaraj Panneerselvam, Pp. 20523-20525

Ipomoea laxiflora H.J. Chowdhery \& Debta (Convolvulaceae): new records for the Western Ghats and semiarid regions

- Sachin M. Patil, Ajit M. Vasava, Vinay M. Raole \& Kishore S. Rajput, Pp. 20526-20529

Counting the cost: high demand puts Bunium persicum (Boiss.) B.Fedtsch. in jeopardy

- Monika Sharma, Manisha Mathela, Rupali Sharma, Himanshu Bargali, Gurinderjit S Goraya \& Amit Kumar, Pp. 20530-20533

First record of Parasitic Jaeger Stercorarius parasiticus (Aves: Charadriiformes: Stercorariidae) from inland freshwater Inle Lake, Myanmar

- Sai Sein Lin Oo, Myint Kyaw, L.C.K. Yun, Min Zaw Tun, Yar Zar Lay Naung, Soe Naing Aye \& Swen C. Renner, Pp. 20534-20536

\section{Book Review}

Capparis of India

- V. Sampath Kumar, Pp. 20537-20538
Publisher \& Host
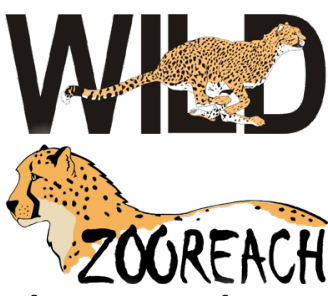

Threatened Taxa 